\title{
Institutions, public debt and growth in Europe
}

\author{
KLAUS MASUCH, Ph.D.* \\ EDMUND MOSHAMMER, MSc* \\ BEATRICE PIERLUIGI, Ph.D.*
}

\author{
Article** \\ JEL: O43, C23, E02, H63 \\ https://doi.org.10.3326/pse.41.2.2
}

\footnotetext{
* Preliminary versions of the paper were presented in 2015 at an IMF internal seminar, NABE conference in Munich, Bruegel seminar in Paris and in 2016 at the European Finance Forum in Frankfurt. It benefited from comments from meeting participants at these events. Without implicating them, very useful comments were received (in alphabetical order) from Daron Acemoglu, John Christopher Bluedorm, Kevin Cardiff, Cristina Checherita-Westphal, Joao Nogueira Martins, Athanasios Orphanides, Peter Praet, Andre Sapir, Jesus Fernandez-Villaverde. The authors would also like to thank to the two anonymous referees for useful comments and suggestions. The views expressed in this paper are those of the authors and they do not necessarily coincide with those of the European Central Bank or the Eurosystem. Edmund Moshammer was trainee at the ECB at the time of writing the paper.

${ }^{* *}$ Received: October 19, 2016

Accepted: March 8, 2017
}

Klaus MASUCH

Principal Advisor, Director General Economics, European Central Bank, Sonnemannstrasse 22, 60314 Frankfurt am Main, Germany

e-mail: klaus.masuch@ecb.europa.eu

ORCID iD: 0000-0002-0274-8712

Edmund MOSHAMMER

Economist, European Stability Mechanism, 6a Circuit de la Foire Internationale, L-1347 Luxembourg

e-mail: e.moshammer@esm.europa.eu

ORCID iD: 0000-0002-9150-0937

Beatrice PIERLUIGI

Advisor, Director General Economics, European Central Bank, Sonnemannstrasse 22, 60314 Frankfurt am Main, Germany

e-mail: beatrice.pierluigi@ecb.europa.eu

ORCID iD: 0000-0003-0905-6409 


\section{Abstract}

This paper provides empirical evidence that supports the view that the quality of institutions is an important determinant of long-term growth in European countries. It shows that an initial high government debt level coupled with institutional quality below the EU average tends to be associated with particularly poor longterm real growth performance. Interestingly, the detrimental effect of high debt levels on long-term growth seems cushioned by the presence of very sound institutions. The paper offers some evidence that sound institutions may be particularly important for long-term growth in countries in which the exchange rate tool is no longer available and less so in countries with flexible exchange rate regimes. The empirical findings on the importance of institutions are robust to various measures of output growth, different measures of institutional indicators, different sample sizes, different country groupings and to the inclusions of additional control variables.

Keywords: quality of institutions and real growth, real convergence in the EU, public governance, structural reforms, public debt, panel estimates

\section{INTRODUCTION}

During the past twenty years, European countries have witnessed very different growth performances. A significant part of these differences cannot be justified by differences in the initial levels of GDP per capita and the related catching-up potential. The ECB in its Economic Bulletin (ECB, 2015) argued that the quality of domestic institutions and governance has a positive impact on economies' per capita income growth and that a lack of real convergence can be "related to several factors, notably weak institutions, structural rigidities, weak productivity growth and insufficient policies to address asset price booms".

Against this background, this paper investigates whether initial levels of the quality of institutions and public debt can help to explain the different long-term growth performances in Europe and why real convergence in the euro area seems to have been lagging behind. To answer this question, the paper builds on two strands of empirical analysis on the determinants of long term growth of a country: first the impact of the quality of institutions and second the role of high debt in affecting GDP growth. The benchmark model links long-term GDP growth with the initial levels of the quality of institutions, government debt (above a threshold) and an interaction term between these two explanatory variables.

Long-term growth is defined as the 15 -year average per capita output growth. While in growth theory this time span may not be sufficient to be qualified as "long-term" growth, in this paper we consider it sufficiently long to derive some robust conclusions for advanced economies. The quality of institutions is based on a composite index including four measurable governance indicators (taken from the World Bank): rule of law, regulatory quality, government effectiveness and control of corruption (in the paper termed "institutional delivery"). These indicators 
try to capture how well national administrative and governmental institutions that determine the environment for economic activities are able to deliver a levelplaying field for all economic actors, prevent rent extraction and waste of resources, and ensure sound economic incentives for investment, innovation and the provision of public goods. Public debt enters in the benchmark model as a dummy variable that takes the value of one only when public debt is above certain thresholds.

The benchmark model is estimated for EU countries, EU plus non-EU OECD and for two sub-groups of countries: countries with fixed exchange rate regimes and those belonging to the euro area, and countries with flexible exchange rate regimes. Results are also shown for the EU excluding Greece and for the EU excluding the CEEC countries which joined the EU in 2004 and 2007, given the very different levels of institutions and debt in the two groups of countries. The sample period includes annual data from 1995 until 2017. Given that the target variable - potential output growth - includes 15 years of data, the explanatory variables run from 1995 until 2002. The econometric approach consists of pooled mean estimates that account for autocorrelation of errors across time, as the 15-year average per capita output growth series are overlapping. The last 15 -year average per capita output growth, e.g. 2002-2017, includes two years of forecasts taken from the European Commission database.

Various robustness exercises have been carried out to enhance the robustness of the results and partly also to control for the risk of reverse causality, for example the use of different proxies for institutional quality, the introduction of additional control variables in the equation. Moreover, the fact that the institutional variable enters the equation as initial condition at time $t$, to explain the subsequent 15 -year average per capita GDP growth, may also tend to alleviate the problem of reverse causality. To test for the possibility that both institutional delivery and long-term growth are affected by deeper country-specific characteristics, the estimates are also carried out with 2 SLS instrumental variables, using legal origin dummies as instruments for institutional delivery. This approach confirms the results of the benchmark model, despite instruments not always being significant. This supports the view that causality seems indeed to run from institutions to long-term growth.

The findings of the paper tend to support the view that the quality of institutions is an important determinant of long-term growth. The results seem particularly important for countries where institutional delivery is below or around the EU average and initial public debt is above a certain threshold (e.g. 60 or $70 \%$ ). To the extent that causality is indeed running from institutions to subsequent long-term growth, such countries could experience significantly higher per capita GDP growth if their institutions were improved. Interestingly, the presence of very sound institutions appears able to offset the detrimental effect of high debt on long-term growth. While this result needs to be treated carefully as it is driven by rather few observations, it might suggest that the debt thresholds above which debt levels are detrimental for growth are not the same across countries, but could 
be endogenous to the quality of public institutions. A possible narrative consistent with these findings could be that sound institutions may help alleviate the debt problem via various channels. For example good institutions may (i) allow for a better (potential growth enhancing) use of government expenditures financed by debt (e.g. the Scandinavian example); (ii) promote stronger growth via sound structural policies; (iii) promote social fairness and allow for more efficient tax administration, thereby reducing the economic and social costs associated with high debt; and/or (iv) ensure that episodes of large increases in debt are followed by sufficiently strong consolidation policies in the subsequent years. Empirical analysis testing for the above channels is beyond the scope of this paper and left for future research.

While the results hold across different group of countries, it appears that the conditions for real convergence are also generally good for the group of euro area and fixed exchange rate countries (for short fixed exchange rate group). At the same time the quality of institutions seems particularly important for this group. While these results are preliminary and require further research, this could reflect that sound institutions - and the associated policies - help to compensate for the lack of the exchange rate tool as adjustment and disciplinary device, supporting the view that improvements in institutions and the associated structural reforms are particularly important for euro area countries to be able to reap the full benefits of monetary union.

The benchmark model is changed in several ways to check the robustness of the results. First the results are assessed against different debt thresholds (corresponding to the EU average, the Maastricht threshold and the EA average); second the model is augmented with the different control variables typically included in the growth literature (such as education attainment, saving rate and government expenditure); third, other measures of institutional quality are used as a proxy for institutional delivery, which allow for extending the sample period considered by 20 years, i.e. advancing the starting date from 1995 to 1975. These changes continue to support the evidence that institutional delivery is a critical determinant of long-term growth in Europe; however the significance of debt thresholds turns out to be less robust to the above changes.

Various robustness exercises are also reported by using different measures of long-term growth and different time-spans. Also, these exercises show that the estimates obtained with the benchmark model are relatively robust to changes in specifications. This is particularly the case for institutional delivery and its interaction with the debt dummy.

There are of course many factors that are not or only partially included in the institutional variables used here, which can enhance longer-term growth. These would include macroeconomic stability, prudent fiscal policies, efficient set-up of university, school and dual education systems, strong incentives for investment in 
human and real capital, a high degree of flexibility and openness in product and labour markets, well capitalised and supervised financial institutions, efficient insolvency frameworks, conditions for an efficient use of capital and labour in the economy, including via economic integration within the EU. The results of this paper are broadly consistent with the view that the Word Bank (or other) indicators measuring the quality of institutions cover key factors and mechanisms, which also determine the probability that governments and societies will in the future support sound policies and reforms in the above areas, enhancing long-term growth. The link between institutional quality and the probability of supporting sound policies and reforms in Europe that enhance long-term growth has however not been tested explicitly in this paper. It is left for further research.

\section{LITERATURE OVERVIEW}

European countries continue to experience quite different long term GDP growth rates, even when accounting for different catching-up potentials related to the initial levels of per capita GDP. Regarding the euro area countries, in the July 2015 edition of the Economic Bulletin the ECB summarises its assessment of the real convergence and the (lack of) catching-up as follows: “... The global financial crisis that started in 2008 has showed that some countries participating in the Economic and Monetary Union (EMU) had severe weaknesses in their structural and institutional set-up. This has resulted in a large and protracted fall in real per capita income levels in these countries since 2008. While there has been real convergence in the European Union (EU) as a whole since 1999 owing to the catching up of Central and Eastern European (CEE) economies, there has been no process of real convergence among the 12 countries that adopted the euro in 1999 and 2001".

Against this background, this paper specifically investigates the role of two initial conditions in explaining long-term growth differences: the quality of national public and economic institutions and the level of public sector debt. The various specifications used can be considered part of the vast empirical analysis testing the notion of conditional convergence; that is the relationship between growth rates and initial conditions.

The paper provides evidence which is consistent with the view that conditions for real convergence are in principle good for countries that no longer have the nominal exchange rate tool (i.e. the group of euro area and fixed exchange rate countries). At the same time the quality of institutions appears very important for longrun growth in general and seems particularly important for this group of countries and/or for countries with initial debt above a certain threshold.

The crucial role of sound and efficient institutions - sometimes also referred to as good governance - in explaining long-run growth was formalised in a number of contributions in early 2000s, showing that countries with weaker institutions find it harder to sustain growth and are more vulnerable to periods of crisis and stagnation (Acemoglu, Johnson and Robinson, 2001; 2002). Acemoglu et al. (2004) show, by 
using a number of historical episodes, how institutions are able to determine the incentives of, and the constraints on, economic actors and shape long-term economic outcomes. In Acemoglu et al. (2004) economic institutions are identified with the structure of property rights and the access to economic resources. Thus, good economic institutions are those that provide security of property rights and relatively equal access to economic resources to a broad cross-section of society. The historical episodes analysis also shows that strong institutions, democracy, transparency and political stability bring about reduced output volatility.

In this paper, we use a definition of economic institutions similar to that in Acemoglu et al. (2004). It is based on four measurable governance indicators (taken from the World Bank Indicators): rule of law, regulatory quality, government effectiveness and control of corruption. These indicators try to capture how the economic structure is able to deliver a level-playing field for all economic actors, ensure that rent extraction and waste of resources are limited and sound economic incentives are in place for encouraging people to invest, innovate, save, solve problems of collective actions and provide public goods.

As well emphasized by Blanchard and Wolfers (2000), when dealing with institutional variables, the problem of their endogeneity to macroeconomic outcomes arises, also on account of the fact that these variables have been generally measured ex-post. Hall and Jones (1999) also stress the endogenous nature of institutions, arguing that institutions might themselves depend on the level of output per worker in an economy. This implies that any research involving institutional variables requires a significant amount of robustness checks. In this paper, we use 2SLS instrumental variables, using legal origin dummies as instruments for institutional delivery, following La Porta et al. (1999) as well as other robustness checks, i.e. different measures of institutions and the inclusion of other structural control variables. By using legal origins we test the hierarchy of institutions hypothesis (Acemouglu et al., 2004), according to which institutions, while they do affect economic performance, are in turn both directly and indirectly influenced by political institutions. Our approach is similar to that of Eicher and Leukert (2009), who use a set of political institutions variable as instruments for economic institutions. However, our instruments do not suffer from an ex-post measurement bias, as they refer to the legal origins of a country. In a similar vein, Hall and Jones (1999) used location and language differences to instrument institutions and showed that differences in output per worker in a sample comprising 127 countries (OECD and developing) are driven by differences in institutions and government policies, which they refer to as social infrastructure. It should be noted that using legal origins as an instrument has been also subject to criticism, as the legal transplantation process appears to have been historically more important than the legal origins for explaining the economic developments of countries (Berkowitz, Pistor and Richard, 2003). As an alternative instrument "human genetic diversity" has been recently used to investigate the impact of corruption on economic growth (Kunieda, Okada and Shibata, 2016). However, this concept 
also suffers from several limitations, in particular related to possible large measurement errors (Ashraf and Galor, 2013).

Our approach does not aim to explain differences in the level but in the growth rate of per capita GDP. When limiting the attention to Europe, there has been a relatively large amount of empirical work on the convergence across countries; however not much attention has been devoted to differences in economic institutions as explanatory factor. For example, substantial empirical work has been done to assess the convergence of transition economies of Eastern European countries (Rapacki and Próchniak, 2009), based on a traditional set of macroeconomic and structural variables. Other work has focused on the identification of "convergence clubs", i.e. country groups within the EU which have in common the level of real income per capita (Borsi and Metiu, 2013), derived from a neoclassical growth model augmented with endogenous technological progress. Borsi and Metiu (2013) found that regional linkages seem to play a significant role in determining the formation of convergence clubs and that euro area countries belong to distinct subgroups, thus clustering is not necessarily related to EMU membership. By 2008, the Commission (2008) had already pointed out that the catching-up processes have been somewhat lower in the EMU than outside it, even when accounting for differences in the initial levels of GDP per capita. Most recently, by means of a counterfactual analysis, using synthetic control methodology, Fernandez and Garcia Perea (2015) argued that the adoption of the euro did not produce the expected permanent increase in the GDP per capita growth rate. While their model does not allow an explanation of why this happened, the authors refer to the lack of rise in intra trade and to the lack of policies to boost productivity as potential causes.

However, empirical work on the institutional determinants of longer-term growth performance of euro area countries has been so far relatively limited. This is mainly due to the fact that the euro area history is new, and fifteen years of monetary union may seem rather short for any long-term growth theory to be properly applicable. This also implies that work on growth differentials and governance in the euro area has so far been more of a narrative nature. For example, Fernandez-Villaverde et al. (2013) discuss an impressive set of qualitative and anecdotal evidence in some euro area countries on the interaction of euro area membership and the loosening of financial and borrowing constraints, and related disincentives for governments to reform. Their analysis does not include an attempt to provide empirical estimates on the impact of deep rooted institutional differences across countries.

Much wider, however, is the empirical literature that links GDP growth performance to structural variables in the OECD countries, in which typically each factor of a production function is directly or indirectly related to institutional or structural variables. For example, Bassanini et al. (2001) show how the accumulation of physical and human capital and policy conditions (e.g. R\&D activity) affects growth. Similarly, Barnes et al. (2013) reports estimates for all OECD countries where GDP per capita growth and its supply side determinants are affected by a 
wide range of structural policies. These estimates show the large impact of labour and product market regulations, tax systems, education, R\&D and FDI policies on real GDP per capita. Our paper is complementary to the above mentioned literature. It focuses on the explanatory power of a parsimonious number of initial conditions on the subsequent long-term GDP per capita growth performance. This is done by looking at eight years of initial conditions, from 1995 to 2002, in terms of starting level of per capita GDP, government debt and quality of economic and public institutions, and for each point in time the subsequent 15-year per capita GDP growth performance. Moreover this paper adds a new dimension to the empirical literature on long-term growth as it investigates the interaction between indebtedness and the quality of institutions.

The link between debt and structural indicators has already been analysed from a different perspective, e.g. by conditioning debt sustainability analysis on a set of structural indicators (Wyplosz, 2007). Papers linking debt with growth have been numerous. Chalk and Tanzi (2002) highlight different channels through which debt can affect growth. In particular, high public debt can put upward pressures on interest rates, which reduces private investment and thus growth; higher debt is ceteris paribus associated with higher expected future taxes, which can reduce expected after-tax returns on investment. Most recently empirical papers linking debt with growth found threshold values above which debt can become harmful for GDP growth (Baum, Checherita-Westphal and Rother, 2013). These threshold effects, which are estimated to occur between 70 to $90 \%$ of GDP depending on the sample used and the definition of debt, have been found to be significant not only in the case of public debt but also for private debt (Cecchetti, Mohanty and Zampolli, 2011).

Contrary to Wyplosz (2007) this paper does not address the issue of debt sustainability per se, but it shows that in the case of a relatively low quality of domestic institutions a high debt level tends to be associated with lower long-term growth. It also does not search for endogenous threshold values due to the fact that the time dimension is relatively limited (i.e. eight years), which implies little countryspecific variability of the debt series. The paper is organised as follows. Section 3 describes the data. Section 4 presents the empirical models and discusses the results. Sections 5 and 6 present a number of variants of the benchmark model and section 7 includes additional robustness check. Section 8 concludes.

\section{DATA ANALYSIS}

The empirical analysis is based on annual data, covering EU countries. ${ }^{1}$ The key variables of interest are: GDP per capita, government debt and an aggregate measure of quality of economic institutions. These initial variables are used to explain the potential GDP per capita growth over the subsequent 15-years. The aggregate measure of economic institutions comes from the Worldwide Governance Indicators (WGI) database published annually by the World Bank (Kaufmann, Kraay and

\footnotetext{
${ }^{1}$ Luxemburg is excluded from the sample, as GDP per capita is not a meaningful variable, given the very large number of employees commuting cross-borders.
} 
Mastruzzi, 2010) $)^{2}$. The full database contains six governance indicators: voice and accountability, political stability and absence of violence, government effectiveness, regulatory quality, rule of law and control of corruption. This paper focuses on the average of the latter four, which captures the quality of economic and administrative institutions, referred to as institutional delivery or institutional quality $^{3}$, while the first two indicators are related to the political setting. The remaining variables (real GDP, potential GDP, population and government debt) are taken from the European Commission database (November 2015).

\section{Chart 1}

Catching-up effects (real GDP per capita in 1999 and potential GDP per capita growth in 1999-2014)

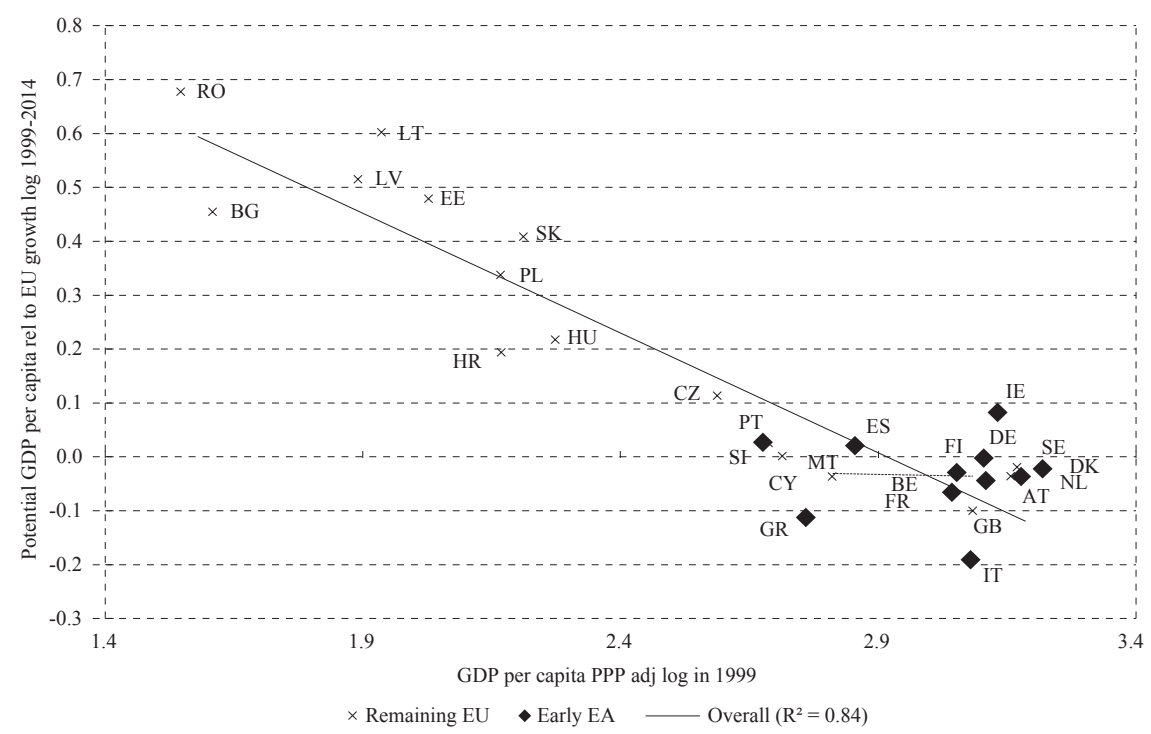

Note: As diamonds early EA countries (i.e. countries that joined the euro area until 2001), as $x$ other EU countries.

Source: ECB computation on EC data.

Chart 1 shows the level of per capita GDP (x-axis) in 1999, plotted against the 15 -year average potential GDP per capita growth (y-axis). The chart distinguishes between the early euro area group (i.e. the countries that joined the euro area up to 2001 - early EA) and the rest of the EU. With an $\mathrm{R}^{2}$ of 0.85 , one can conclude that initial GDP conditions are able to explain a great deal of the variability in the subsequent potential GDP per capita growth. This is in line with the expectations that countries with lower income per capita will grow faster than countries with higher income per capita. Stronger GDP growth in the period 1999-2014 in the

\footnotetext{
${ }^{2}$ Available at $<$ http://info.worldbank.org/governance/wgi/index.aspx $>$.

${ }^{3}$ See Helliwell et al. (2014).

${ }^{4} \mathrm{http} / / / \mathrm{ec}$. europa.eu/economy_finance/eu/forecasts/2015_autumn_forecast_en.htm for EU-28 data is available from 2001 to 2017. For EU-27 excluding the latest entrant Croatia, data from 1998 onwards is available.
} 
rest of the EU can also be associated with the impact of the EU membership which took place in 2004 (Campos, Coricelli and Moretti, 2014).

However, the chart shows that certain countries have fallen out from this simple prediction model. For example Greece, Portugal, Slovenia, Cyprus, Italy, Bulgaria, Croatia show particularly high negative residuals while the Baltic countries, Romania, Slovakia and Ireland were growing very fast compared to their initial GDP level.

In this paper the simple catching-up model shown in chart 1 is extended by considering institutional delivery and the level of public debt. Chart 2 shows the level of the institutional delivery indicator across the EU in two periods of time: 1999 and 2014. This indicator refers to the World Bank 215 country sample, where a positive value means good institutional delivery. Its statistical distribution follows a standard normal random variable, i.e. with zero mean, unit standard deviation, and ranges approximately from -2.5 to 2.5 . In this paper, we centre this indicator to the EU27 sample average in 1996. Chart 2 shows that there is a large variability across the EU countries in terms of institutional quality, and that, as expected, richer countries enjoy higher institutional delivery. Interestingly however the chart shows a very large variability inside the early EA group (dashed bars) despite much more limited per capita GDP differences across this group of countries. Finally the chart also shows that during the past 15 years many of the early EA group (with the strongest drop in Greece, Italy and Spain) saw a worsening of the institutional delivery indicator. The analysis of the evolution of institutional delivery is presented in annex 1 with a diff-in-diff computation. This picture seems consistent with the findings in Fernandez-Villaverde et al. (2013), which emphasises the disincentives to implement reforms after the stage 3 of EMU.

Chart 3 puts together the residual from the simple catching-up model (chart 1) and the institutional delivery in 1999, taking into account the level of the government debt. This is done by representing the size of countries circles according to their government debt to GDP ratio. Chart 3 shows that the quality of institutions seem to matter most, in the sense that it is associated with subsequent relative GDP growth, for relatively high debt countries, i.e. for countries with government debt at least above $50 \%$ of GDP. When focusing on the euro area countries (white dots) a clear positive relationship emerges between the institutional quality and the residual from the simple catching-up model. This chart seems to indicate that institutional quality and government debt (above a certain level) could be two explanatory variables of the long-term GDP performance in the EU, and in particular in the euro area. 


\section{Chart 2}

Institutional delivery indicator (1999 vs. 2014)

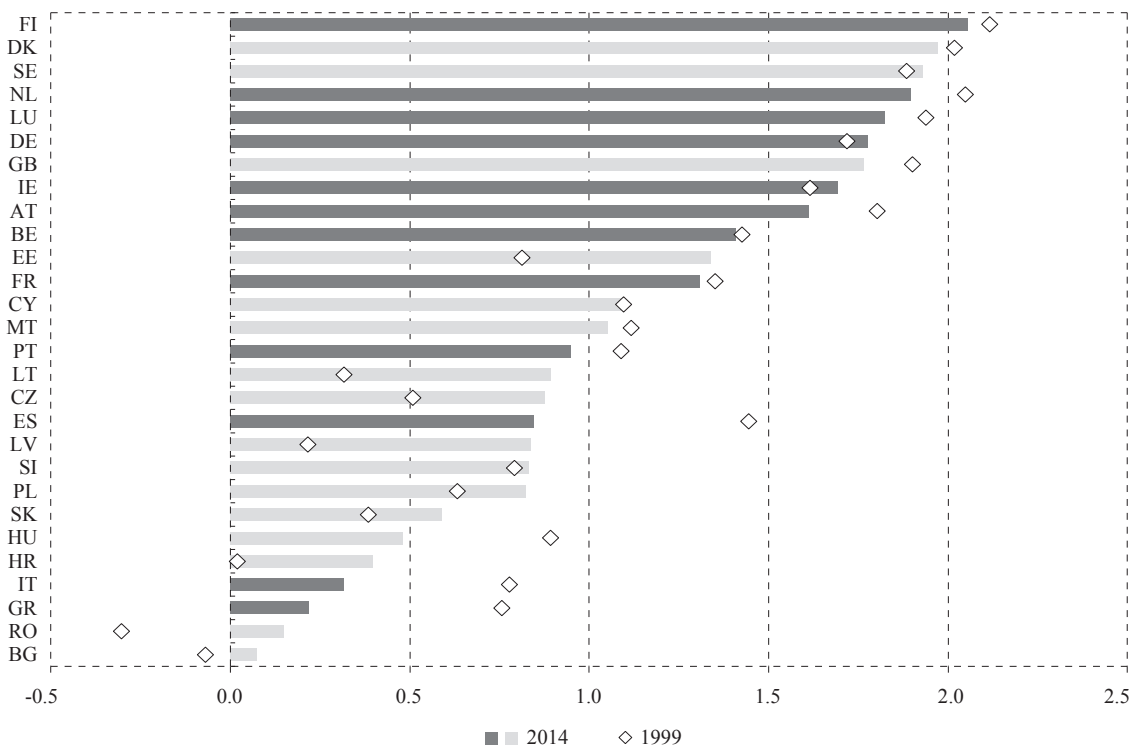

Note: Average of four indicators: government effectiveness, regulatory quality, rule of law and control of corruption. Dashed early EA countries and blank rest of EU.

Source: Authors' computation on WDI data.

\section{Chart 3}

Institutions, debt and country-groups

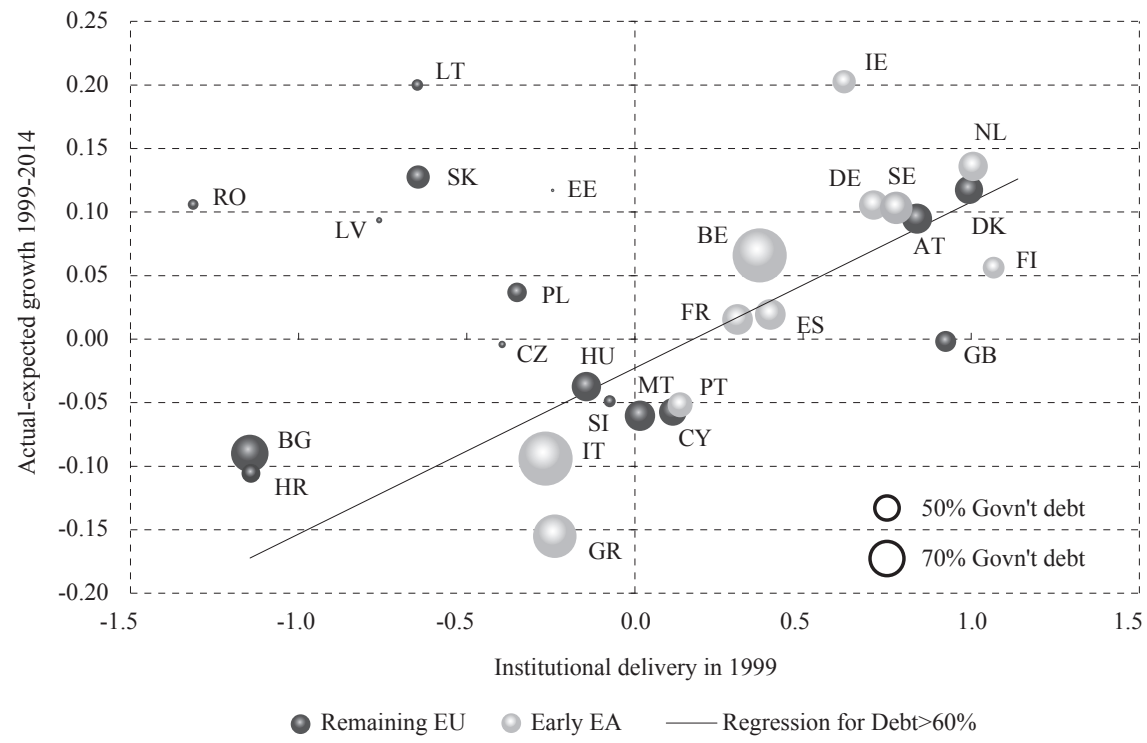

Source: ECB computation on EC and World Bank data. 
Before econometric tests are made, the relationship between the variables plotted in chart 3, table 1 provides a summary of the key indicators at play. The table distinguishes between five group of countries: the whole EU, countries with government debt higher than the $60 \%$ Maastricht threshold, the countries with government debt lower than the 60\% Maastricht threshold, the Early EA, which refers to the countries who joined the euro area between 1999 and 2001; and the transition countries, which refers to the Central and East-European countries which joined the EU in 2004 and 2007. The table shows un-weighted averages across the different groups of the cumulated potential per capita GDP growth in 1999-2014, the level of GDP per capita in 1999, the institutional delivery in 1999, 2007 and 2014 and government debt in $1999^{5}$. Across the variable reported it is interesting to note that higher debt level in 1999 has been associated with lower per capita potential growth. It also shows that institutional delivery decreased not uniformly across the various group of countries. It has been constantly falling in the high debt countries and in the early EA, constantly improving in the transition countries and falling since 2007 in the low debt countries.

\section{TABLE 1}

Key summary statistics of the indicators used in the regression analysis ${ }^{6}$

\begin{tabular}{|c|c|c|c|c|c|}
\hline & $\mathbf{E U}$ & Debt $<\mathbf{6 0}_{1999}$ & Debt $>\mathbf{6 0}_{1999}$ & Early EA & $\begin{array}{l}\text { Transition } \\
\text { countries }\end{array}$ \\
\hline $\begin{array}{l}\text { Pot. GDP per capita } \\
\text { PPPadj growth } \\
\text { 1999-2014 }\end{array}$ & 80.24 & 95.04 & 55.91 & 49.02 & 126.05 \\
\hline $\begin{array}{l}\text { GDP per capita in thsd } \\
\text { PPPadj EUR }{ }_{1999}\end{array}$ & 15.65 & 14.15 & 18.72 & 20.49 & 8.81 \\
\hline WGI Delivery $_{1999}$ & 0.034 & 0.018 & 0.177 & 0.445 & -0.624 \\
\hline${ }_{\text {WGI Delivery }} 2007$ & 0.091 & 0.058 & 0.157 & 0.359 & -0.427 \\
\hline WGI Delivery $_{2014}$ & 0.062 & 0.011 & 0.097 & 0.271 & -0.376 \\
\hline $\begin{array}{l}\text { Government Debt \% } \\
\text { GDP }_{1999}\end{array}$ & 52.41 & 37.67 & 76.01 & 69.13 & 32.38 \\
\hline Observations $_{1999}$ & 27 & 16 & 10 & 11 & 11 \\
\hline
\end{tabular}

Source: ECB computation on EC and World Bank data.

\section{THE EMPIRICAL MODEL AND ESTIMATION RESULTS}

\subsection{THE EU SAMPLE AND THE MAASTRICHT DEBT THRESHOLD}

The correlations chart shown in the previous section (chart 3) seems to indicate that the quality of institutions may be more important to explain the long-term GDP performance in the early EA group than in the rest of the EU. The analysis has also shown that there is a high correlation between level of debt and early euro area membership. Against the above evidence, this section tests the validity of a parsimonious empirical model capturing the linkages between quality of institutions and level of debt.

\footnotetext{
${ }^{5}$ There is no European Commission data on the level of Croatian government debt in 1999.

${ }^{6}$ General government debt data are reported in annex 2 .
} 
The estimated benchmark model takes the following specification:

$$
\Delta y_{c, t}=\alpha+\beta_{y} y_{c, t}+\beta_{D} D_{c, t}+\beta_{I} I_{c, t}+\beta_{D I} D_{c, t} I_{c, t}+\varepsilon_{c}
$$

where:

$\Delta y_{c, t}$ is the 15-year average GDP per capita growth computed starting at time $t$ (i.e. log change of potential purchasing power (PPS) adjusted GDP per capita) with $t$ running from 1995 to 2002 for country $c$.

$y_{c, t}$ is the log starting level of the PPS adjusted GDP per capita at time $t$ for country $c$.

$D_{c, t}$ is a dummy, at time $t$ for country $c$, which takes the value of 1 if government debt is greater than a certain threshold. In our benchmark model we assume that the threshold is $60 \%$ of GDP (Maastricht threshold).

$I_{c, t}$ measures the institutional delivery at time $t$ for country $c$, the index is centred at the EU average level and we apply a 3-year centred moving average. This is done to include as many as possible back data, which prior to 2002 were available on a biannual basis.

$D_{c, t} I_{c, t}$ is the interaction between the latter two indicators.

Given that the last starting data point is 2002 the corresponding GDP growth interval, i.e. 2002-2017, includes two years of forecast, which is taken from the European Commission. For Bulgaria debt data are available from 1997 and for Croatia debt data are available from 2001 onwards.

As a result the panel consists of 208 data points $(25 * 8+6+2)$. Given that the panel's GDP growth periods are overlapping, to account for autocorrelation of errors across time we use a pooled OLS regression with standard errors clustered across time. The choice of the pooled OLS regression instead of a country-fixed effect model is due to the use of the country-specific institutional delivery variable, which contains very little variability between 1995 and 2002, plays the role of a country-specific constant.

We estimate the model by using both ordinary least squares and 2SLS instrumental variables. The latter method is used to account for the possibility that deep cultural, legal and political differences underlie different economic institutions (Acemoglu, Johnson and Robinson, 2004; 2005). Thus we decide to use the approach of La Porta et al. (1999), where legal origin dummies are used as instruments for the economic variables. ${ }^{7}$ In view of the presence of the interaction term two instrumental equations are estimated in the first step:

\footnotetext{
${ }^{7}$ In La Porta et al. (1999) countries are grouped according to English (CY, IE, UK), French (MT, BE, ES, FR, GR, IT, NL, PL), German (AT, DE), Soviet (EE, LT, LV, SI, SK, BG, CZ, HR, HU, PL, RO) and Scandinavian (FI, DK, SE) legal origins. As there are doubts about the Soviet legal origin of SI and HR, robustness checks have been carried out by using German origin for these countries (see annex 7). Annex 7 also reports the outcome of 2SLS using human diversity as instrumental variable.
} 


$$
\begin{gathered}
I_{c, t}=\gamma_{0}+\gamma_{1} y_{c, t}+\gamma_{1} D_{c, t}+\gamma_{2} L O_{c, t}+\gamma_{3} D_{c, t} L O_{c, t}+\varepsilon_{c} \\
D_{c, t} I_{c, t}=\delta_{0}+\delta_{1} y_{c, t}+\delta_{1} D_{c, t}+\delta_{2} L O_{c, t}+\delta_{3} D_{c, t} L O_{c, t}+\varepsilon_{c}
\end{gathered}
$$

where $L O$ stands for legal origin. In the second step the fitted values of $I_{c, t}$ in equation (2) and of $D_{c, t} I_{c, t}$ in equation (3) are plugged into the original equation (1).

\section{TABLE 2}

Estimation output of equation (1)

\begin{tabular}{|c|c|c|}
\hline Explanatory variables & OLS & 2SLS \\
\hline Log GDP (PPP) & $\begin{array}{l}-0.589 * * * \\
(0.0386)\end{array}$ & $\begin{array}{l}-0.611 * * * \\
(0.0413)\end{array}$ \\
\hline Institutional delivery & $\begin{array}{l}0.0951 * * * \\
(0.0317)\end{array}$ & $\begin{array}{l}0.116^{* * *} \\
(0.0394)\end{array}$ \\
\hline$(\mathrm{Debt}>60)$ & $\begin{array}{l}-0.0394 * \\
(0.0197)\end{array}$ & $\begin{array}{l}-0.0357^{*} \\
(0.0186)\end{array}$ \\
\hline$($ Debt $>60) \times$ Institutional delivery & $\begin{array}{l}0.131 * * * \\
(0.0283)\end{array}$ & $\begin{array}{l}0.123 * * * \\
(0.0289)\end{array}$ \\
\hline Constant & $\begin{array}{l}2.127 * * * \\
(0.0988)\end{array}$ & $\begin{array}{l}2.181 * * * \\
(0.105)\end{array}$ \\
\hline Observations & 208 & 208 \\
\hline R-squared & 0.911 & 0.910 \\
\hline
\end{tabular}

15-year average per capita potential growth

Robust standard errors in parentheses.

$* * * p<0.01, * * p<0.05, * p<0.1$

The estimation results are shown in table $2 .{ }^{8}$ The table shows that the catching up effect, i.e. the impact of the initial level of GDP per capita, is highly significant in both regressions and, as expected, it indicates that higher initial GDP per capita is associated with subsequently lower long-term per capita GDP growth. Moving from one estimation method to another does not impact the significance or the size of the coefficient. The institutional delivery indicator is significant and positive, meaning that stronger quality of institutions is correlated with subsequent higher per capital long-term GDP growth. This result also holds for both estimation methods. Debt dummies are always negatively significant: higher government debt levels reduce long-term GDP per capita growth irrespective of the estimation method. Interestingly, the $60 \%$ threshold used for the debt dummy appears significant. The interaction terms are positively highly significant. When looking at the debt dummy and at the interaction term jointly one can conclude that in the presence of high debt, an improvement of institutions is associated with higher growth potential, and a deterioration is instead associated with lower growth potential. This conclusion holds across both estimation methods. The main takeaway of this exercise is that countries with high debt and low institutional delivery would be significantly better off if they were able to increase the quality of their

\footnotetext{
${ }^{8}$ Annex 3 reports step 1 estimates of the 2SLS.
} 
institutions. For high levels of institutional delivery the model suggests that high debt is not a problem. This is the result of the inclusion in the sample of countries that had both high debt and very good institutional delivery between 1995 and 2002 and robust growth afterwards (e.g. Belgium). ${ }^{9}$

\section{Chart 4}

Contributions to the cumulative potential GDP per capita growth - estimated equation (1)

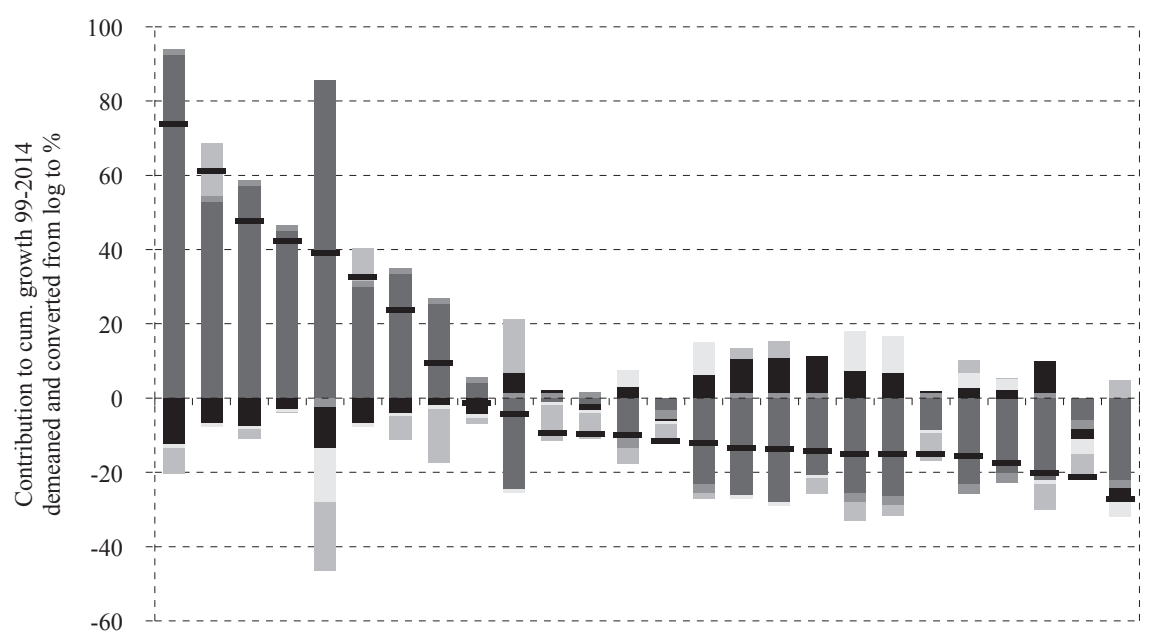

RO LT LV EE BG SK PL HU CZ IE PT SI ES MT DE DK NL FI SE AT CY BE FR GB GR IT

घCatching-up $\backsim$ Debt $>60 \quad$ Institutions Debt $>60 \mathrm{x}$ Institutions $\backsim$ Residual $-15 \mathrm{yr}$ growth

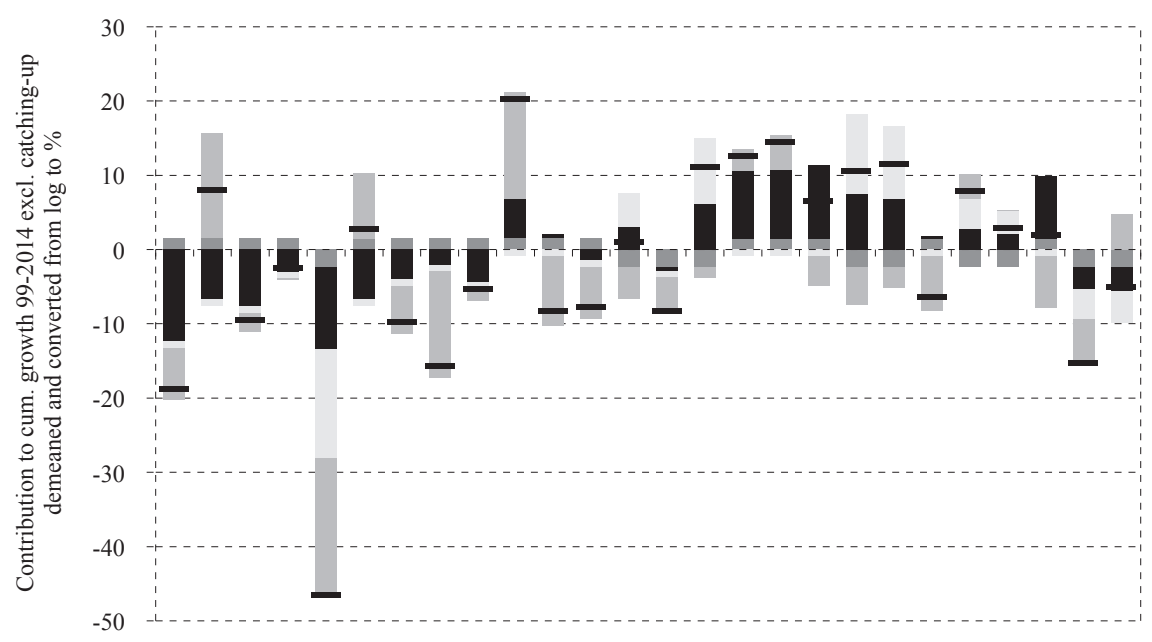

RO LT LV EE BG SK PL HU CZ IE PT SI ES MT DE DK NL FI SE AT CY BE FR GB GR IT $\llbracket$ Debt $>60$-Institutions Debt $>60 \mathrm{x}$ Institutions $\backsim$ Residual $-15 \mathrm{yr}$ growth excl. catching-up

Source: Authors' computation on EC and World Bank data.

\footnotetext{
${ }^{9}$ It is well known that Belgium conducted sound fiscal policies with high primary surpluses after joining the euro area. Possibly, good institutions are conducive to disciplined fiscal policies.
} 
Chart 4 visualizes the regression result of the first column of table 2 . The indicators are demeaned and transformed from log to percentages for better readability. The results are shown for the year 1999 (explanatory variables) and for the per capita GDP growth in 1999-2014. The chart shows in the upper panel all the contributions and in the lower panel the contribution of institutional delivery, debt and the interaction term on the per capita GDP growth corrected for the caching up term. While the upper chart clearly indicates that the largest contribution to per capita potential growth is the level of GDP per capita in most EU non-EA countries, also the contribution of the remaining explanatory variables is important. In particular, the contribution of institutions and debt is generally more relevant for the euro area countries than for the rest of the EU.

\subsection{CHANGING THE COUNTRY COVERAGE AND THE DEBT THRESHOLD}

Our benchmark model (1) is also estimated by using different country groups and different debt thresholds. In this section we only consider the OLS estimates in view of the similarity of results obtained with 2SLS (2SLS estimates are reported in annex 3).

Changing the country coverage allows to test if the three types of initial conditions (GDP per capita, debt and institutions) used in model (1) change their significance for different country groups and different exchange rate regimes. Table 3 shows that when enlarging the group by other OECD countries (based on data availability) the sign and significance of the estimated coefficients remain unaltered. The table also shows the results for 2 sub-groups: the euro area plus fixed exchange rate countries in the EU, and the countries (EU plus other OECD) with flexible exchange rates. It appears very important to test if institutional quality matters more in the presence of fixed exchange rate regimes, given that the absence of the exchange rate tools takes away a degree of flexibility, which would need to be compensated with structural reforms. While the significant drop of observations makes the results less robust, it seems that the model works better for the fixed exchange rate group than for the flexible exchange rate group. In particular, institutional delivery seems more important for the group of countries that have fixed exchange rates or are in the euro area than in countries with flexible exchange rate regimes.

The results seem to indicate that in the fixed exchange rate group (with 21 countries) catching-up conditions are slightly better than in the larger and mixed groups (with 27 or 33 countries), provided that institutions are strong. In the fixed exchange rate group the significance of the debt dummy drops; however the interaction term remains highly significant, indicating that the quality of institutions is particularly important in the presence of high debt. Additional robustness checks for subgroups of countries are shown in annex 4. In particular, when considering CEECs alone, the variables on institutions lose significance, suggesting that institutional quality matters less at the initial stages of catching-up, when the catching- 
up potential is still large, while initially other considerations (including the debt level) may be more important. ${ }^{10}$

\section{TABLE 3}

Changing the country coverage (OLS estimates)

\begin{tabular}{|c|c|c|c|c|}
\hline & $\begin{array}{l}\text { EU } \\
(27)\end{array}$ & $\begin{array}{c}\text { EU + other OECD } \\
\text { (33) }\end{array}$ & $\begin{array}{c}\text { Fixed ER } \\
(21)\end{array}$ & $\begin{array}{c}\text { Flexible ER } \\
\text { (12) }\end{array}$ \\
\hline \multirow{2}{*}{ Log GDP (PPP) } & $-0.589 * * *$ & $-0.551 * * *$ & $-0.634 * * *$ & $-0.402 * * *$ \\
\hline & $(0.0386)$ & $(0.0468)$ & $(0.0483)$ & $(0.0735)$ \\
\hline \multirow{2}{*}{ Institutional delivery } & $0.0951 * * *$ & $0.0904 * *$ & $0.124 * *$ & 0.00785 \\
\hline & $(0.0317)$ & $(0.0391)$ & $(0.0465)$ & $(0.0765)$ \\
\hline \multirow{2}{*}{$($ Debt $>60)$} & $-0.0394 *$ & $-0.0716^{* *}$ & -0.0507 & -0.0895 \\
\hline & $(0.0197)$ & $(0.0297)$ & $(0.0322)$ & $(0.0517)$ \\
\hline$($ Debt $>60) x$ & $0.131 * * *$ & $0.114 * * *$ & $0.133 * * *$ & 0.0873 \\
\hline Institutional delivery & $(0.0283)$ & $(0.0413)$ & $(0.0425)$ & $(0.069)$ \\
\hline \multirow{2}{*}{ Constant } & $2.127 * * *$ & $2.032 * * *$ & $2.237 * * *$ & $1.657 * * *$ \\
\hline & $(0.0988)$ & $(0.118)$ & $(0.121)$ & $(0.186)$ \\
\hline Observations & 208 & 246 & 160 & 86 \\
\hline R-squared & 0.911 & 0.849 & 0.880 & 0.834 \\
\hline
\end{tabular}

Robust standard errors in parentheses.

$* * * p<0.01$, ** $p<0.05, * p<0.1$

Other OECD: CA, IS, JP, NO, TR, US.

Flexible ER: CZ, GB, HU, PL, RO, SE, CA, IS, JP, NO, TR, US.

Fixed ER (early EA and fixed exchange rate and late EA joining countries): $C Y, E E, L T, L V, M T$, $S I, S K, B G, D K, H R$.

Changing the debt threshold allows us to test whether the results depend on a specific debt level and if institutions matter differently for low versus high debt. Three cases are considered:

- A dummy that takes the value of 1 when government debt is above $50 \%$ of GDP. This value was chosen because a value around $50 \%$ of GDP was the un-weighted average of EU countries debt level in 1999 (the average EU27 debt level in the range 1995 to 2002 is $52 \%$ of GDP).

- A dummy that takes the value of 1 when Government Debt is above $70 \%$ of GDP. This value was chosen because a value close to 70\% of GDP was the un-weighted average of Early EA countries debt level in 1999 (the average Early EA debt level in the range 1995 to 2002 is $71 \%$ of GDP).

- Government debt to GDP ratio enters directly in the equation, while the interaction term is constructed with actual debt in deviation from the $60 \%$ of GDP threshold.

\footnotetext{
${ }^{10}$ Annex 4 reports the estimates for the EU15 and the CEECs countries (transition countries in table 1) separately, to take into account the differences between the two groups in terms of GDP per capita, initial level of debt and institutions. The same exercise is shown for the whole EU and EU15 excluding Greece, to test if Greece could be driving the results. Table A7a in annex 4 shows the results are robust when considering the EU15 groups and when excluding Greece from the whole EU and EU15 group.
} 
TABLE 4

Changing debt thresholds (OLS) - baseline sample EU27

15 year average potential GDP growth (in PPP)

\begin{tabular}{|c|c|c|c|c|}
\hline Debt threshold & $\begin{array}{c}\mathbf{T}=\mathbf{6 0} \\
\text { Baseline }\end{array}$ & $\mathbf{T}=\mathbf{5 0}$ & $T=70$ & $\begin{array}{l}\text { No threshold debt } \\
\text { centred at } 60 \% \text { for } \\
\text { the interaction term }\end{array}$ \\
\hline Log GDP (PPP) & $\begin{array}{l}-0.589 * * * \\
(0.0386)\end{array}$ & $\begin{array}{l}-0.567^{* * *} \\
(0.0413)\end{array}$ & $\begin{array}{l}-0.600^{* * *} \\
(0.0396)\end{array}$ & $\begin{array}{l}-0.556^{* * *} \\
(0.0412)\end{array}$ \\
\hline $\begin{array}{l}\text { Institutional } \\
\text { delivery }\end{array}$ & $\begin{array}{l}0.0951^{* * *} \\
(0.0317) \\
\end{array}$ & $\begin{array}{c}0.0663^{*} \\
(0.0348) \\
\end{array}$ & $\begin{array}{l}0.122^{* * *} \\
(0.0330) \\
\end{array}$ & $\begin{array}{l}0.153 * * * \\
(0.0299)\end{array}$ \\
\hline$($ Debt $>T)$ & $\begin{array}{l}-0.0394 * \\
(0.0197) \\
\end{array}$ & $\begin{array}{l}-0.0670^{* *} \\
(0.0243)\end{array}$ & $\begin{array}{l}-0.0272 \\
(0.0249) \\
\end{array}$ & $\begin{array}{l}-0.000459 \\
(0.000391)\end{array}$ \\
\hline $\begin{array}{l}(\text { Debt }>\mathrm{T}) \mathrm{x} \\
\text { Institutional } \\
\text { delivery }\end{array}$ & $\begin{array}{l}0.131 * * * \\
(0.0283)\end{array}$ & $\begin{array}{l}0.150 * * * \\
(0.0291)\end{array}$ & $\begin{array}{l}0.120 * * * \\
(0.0348)\end{array}$ & $\begin{array}{l}0.00291 * * * \\
(0.000571)\end{array}$ \\
\hline Constant & $\begin{array}{l}2.127 * * * \\
(0.0988)\end{array}$ & $\begin{array}{l}2.080 * * * \\
(0.103)\end{array}$ & $\begin{array}{l}2.154 * * * \\
(0.102) \\
\end{array}$ & $\begin{array}{l}2.013 * * * \\
(0.105)\end{array}$ \\
\hline Observations & 208 & 208 & 208 & 208 \\
\hline R-squared & 0.911 & 0.926 & 0.900 & 0.917 \\
\hline
\end{tabular}

Robust standard errors in parentheses.

$* * * p<0.01, * * p<0.05, * p<0.1$

Table 4 shows that the estimated model is robust to a change in the debt threshold. The institutional delivery term coefficient increases its size with the inclusion of a higher debt dummy. The debt dummy loses significance, however, when the threshold is set at $70 \%$ of GDP, while it gains significance when the dummy is set at $50 \%$ of GDP. The loss of significance might be related to the fact that between 1995 and 2002 very few countries in the EU sample had debt levels above this threshold. As in the previous specification, this result seems to point to a relatively higher importance of institutional delivery for the expected long-term per capita growth in the case of highly indebted countries. There are several possible channels via which institutions may alleviate the debt problem. Good institutions may (i) allow for a better (potential growth enhancing) use of government expenditures financed by debt (e.g. the Scandinavian example); (ii) promote stronger growth via sound structural policies; and/or (iii) promote social fairness and allow for more efficient tax administration, thereby reducing the economic and social costs associated with high debt.

\subsection{SOME COUNTERFACTUAL EXERCISES}

For an intuition of what lies behind the estimated models a few numerical counterfactual exercises could be useful. These exercises are carried out on the basis of the coefficient reported in table 4 with the three debt-threshold dummies. We consider five countries in 1999: two high debt countries with below EU average institutional delivery (IT and GR), a low debt country with below EU average institutional delivery (SI) and two countries with initial debt between 50 and $60 \%$ with institutional delivery above the EU average (FR and PT), but well below the three best performers (FI, NL and DK). 
In the first exercise (exercise 1 in table 5) we assume that these five countries had been able by 1999 to achieve debt below the debt thresholds included in table 4 . According to the results reported in table 4 debt below $50 \%$ would have been associated with substantial additional annual real GDP growth over the period 19992014. For example in case of initial debt below the threshold of $50 \%(60 \%)$ the associated additional annual real growth per annum would have been $0.8(0.5)$ percentage points in Italy, 0.7 (0.5) p.p. in Greece, 0.3 p.p. in Portugal and 0.1 p.p. in France (as Slovenia had below 50\% debt in 1999 this exercise is not relevant for this country).

In the second counterfactual exercise, we assume a starting level of debt below the Maastricht threshold of $60 \%$ and in addition a convergence to the three best institutional delivery performers in the EU (e.g. FI, NL and DK). ${ }^{11}$ This starting position would have been associated according to the models in table 4 with an additional 15 year average annual per capita growth of 1.5 percentage points per year in Italy, 1.4 p.p. in Greece, 0.7 p.p. in Slovenia, 0.6 p.p. in Portugal and 0.5 p.p. in France (table 5). ${ }^{12}$

\section{TABLE 5}

\section{Counterfactual exercises}

Exercise 1 - Average annual growth impact of reducing debt to below threshold (in \%)

\begin{tabular}{|c|c|c|c|c|c|c|c|c|c|c|c|c|c|c|c|}
\hline & \multicolumn{3}{|c|}{ IT } & \multicolumn{3}{|c|}{ SI } & \multicolumn{3}{|c|}{ FR } & \multicolumn{3}{|c|}{ PT } & \multicolumn{3}{|c|}{ GR } \\
\hline Model & D50 & D60 & $\mathrm{D} 70$ & D50 & D60 & D70 & D50 & D60 & D70 & D50 & D60 & D70 & D50 & D60 & D70 \\
\hline $\begin{array}{l}\text { Contribution } \\
\text { debt }\end{array}$ & 0.46 & 0.27 & 0.18 & 0 & 0 & 0 & 0.46 & 0.27 & 0 & 0.46 & 0 & 0 & 0.46 & 0.27 & 0.18 \\
\hline $\begin{array}{l}\text { Contribution } \\
\text { interaction term }\end{array}$ & 0.27 & 0.24 & 0.22 & 0 & 0 & 0 & -0.3 & -0.3 & 0 & -0.1 & 0 & 0 & 0.24 & 0.21 & 0.19 \\
\hline Total & $\overline{0.75}$ & $\overline{0.51}$ & $\overline{0.41}$ & 0 & 0 & 0 & $\overline{0.14}$ & 0 & 0 & $\overline{0.32}$ & 0 & 0 & $\overline{0.72}$ & $\overline{0.49}$ & 0.38 \\
\hline
\end{tabular}

\section{Exercise 2 - Average annual growth impact of reducing debt to below threshold} and moving institutions to EU top 3 (in \%)

\begin{tabular}{|c|c|c|c|c|c|}
\hline & IT & SI & FR & PT & GR \\
\hline $\begin{array}{l}\text { Contribution } \\
\text { institutional } \\
\text { delivery }\end{array}$ & 0.87 & 0.73 & 0.47 & 0.59 & 0.85 \\
\hline $\begin{array}{l}\text { Contribution } \\
\text { debt }\end{array}$ & 0.27 & 0 & 0.27 & 0 & 0.27 \\
\hline $\begin{array}{l}\text { Contribution } \\
\text { interaction term }\end{array}$ & 0.24 & 0 & -0.3 & 0 & 0.21 \\
\hline Total & 1.45 & 0.73 & 0.47 & 0.59 & 1.4 \\
\hline
\end{tabular}

\footnotetext{
${ }^{11}$ Note that for PT and SI this counterfactual result is only associated with improved institutions, as the initial debt level in 1999 was below $60 \%$, while for the other three countries the results reflect both lower debt levels and improved institutions at the start of 1999 , compared to the actual values.

${ }^{12}$ Comparing the first and the second exercise suggests that, e.g. in the case of Greece 0.5 p.p. higher annual real growth is associated with the lower initial debt level, and an additional 0.9 p.p. annual growth is associated with a much improved institutional quality, given debt below $60 \%$. Given that the importance of above average institutions increases with the debt threshold, debt above the higher threshold $(70 \%)$ coupled with very good institutions can be associated with even higher real growth. To remain on the prudent side, we do not think that this effect should be included in the counterfactual exercises, also as it seems driven by relatively few observations. In any case, the counterfactual result of the impact of better institutions on long-term growth appears rather large even without this effect.
} 


\section{EXPANDING THE ORIGINAL MODEL}

The empirical growth literature usually contains a much larger set of macroeconomic variables included among the regressors. These variables do not usually cover the institutional set-up as captured by the institutional delivery indicators but other structural characteristics of the economy, such as the level of education, the saving rate, trade openness, the share of government expenditure on top of the initial level of GDP per capita (Barro, 1998; 1991; Barro and Sala-i-Martin, 1995; Easterly and Rebelo, 1993). To check whether model (1) could potentially suffer from an omitted variable problem this section looks at the outcome of an augmented model:

$$
\Delta y_{c, t}=\alpha+\beta_{y} y_{c, t}+\beta_{D} D_{c, t}+\beta_{I} I_{c, t}+\beta_{D I} D_{c, t} I_{c, t}+\beta_{z} Z_{c, t}+\varepsilon_{c}
$$

where $Z_{c, t}$ is a matrix which includes the following variables: trade openness (imports + exports in percent GDP); government expenditures (adjusted for bank recapitalization in percent of GDP); households savings rate; participation rate (labour force as $\%$ of working age population); level of education (percentage of the working age population with at least upper secondary education). These variables are typically included in regression analyses, which try to explain longterm growth differences across countries.

Table 6 reports the estimation results of the expanded model (4). It shows the results of six variants of the benchmark model, by using an incremental approach. Table 6 shows that the institutional delivery and the interaction term remain highly significant throughout variants (1) to (6). By contrast the debt threshold dummy loses significance in four out of the six variants. Among the additional variables, table 6 shows that, while the sign of the additional variables is correct, only the level of education seems to have some limited significance in variant (6), while all other variables are found to be insignificant and are also not able to alter the validity of the original model.

Overall, these exercises show that the parsimonious model seems relatively robust to the inclusions of additional macroeconomic/structural variables. The fact that the latter variables are not found to be significant might have different explanations: first, this model aims at explaining growth performances across similarly developed economies while the additional variables typically explain growth differences across developed and developing countries; second, some of the additional variables might present some degree of collinearity with the institutional delivery, this is particularly the case of education, which is not significant in (5) but only in variant (6); third, the time-span (i.e. 8 years running from 1995 to 2002) implies that there is a relatively limited time-series variability which might also reduce the significance of the additional explanatory variables. 
15 year average potential GDP growth (in PPP)

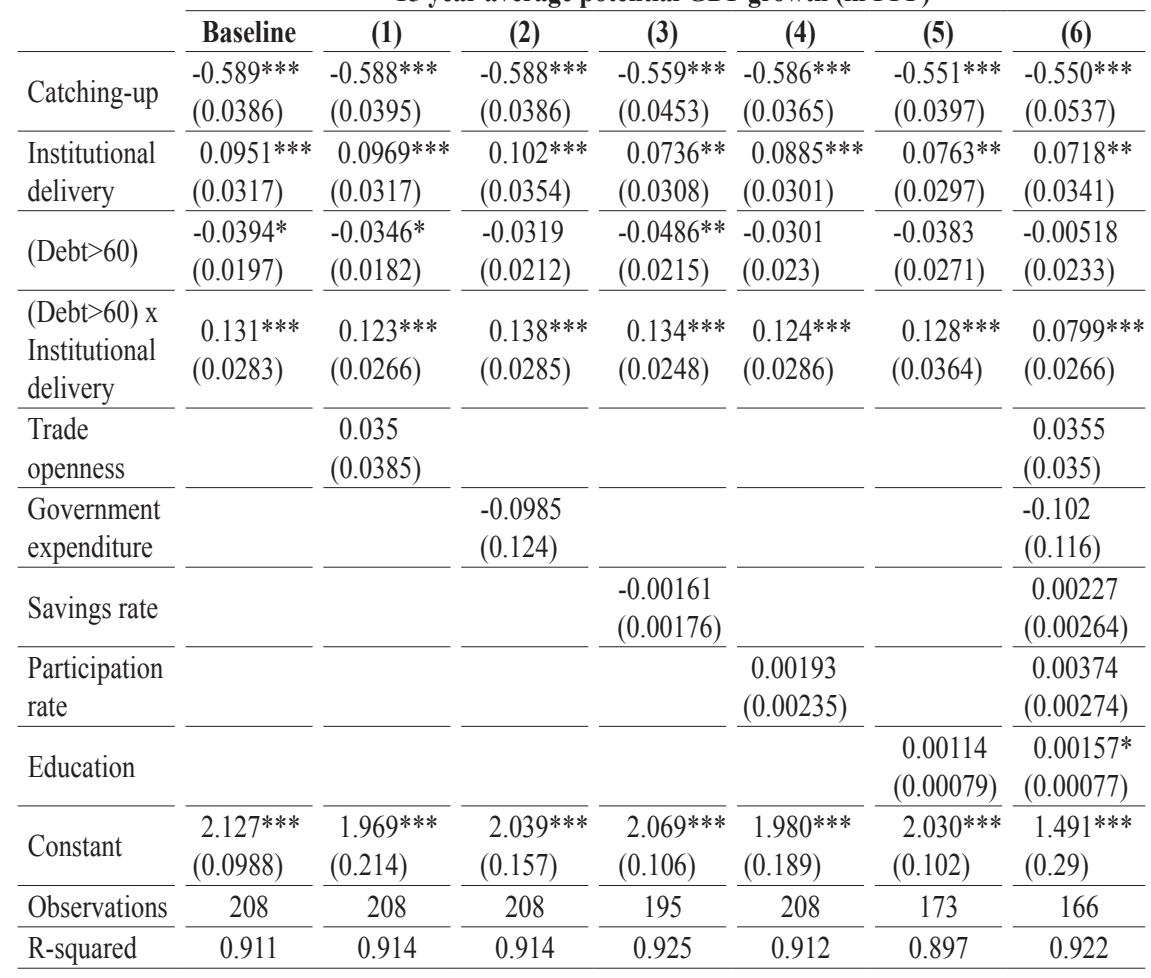

Robust standard errors in parentheses.

$* * * p<0.01, * * p<0.05$, * $p<0.1$

\section{EXPANDING THE SAMPLE PERIOD AND TESTING FOR DIFFERENT PROXY OF INSTITUTIONAL QUALITY}

The relatively limited time variation, from 1995 to 2002, and the fact that institutional delivery indicator moves very slowly through time might lead to the conclusion that the time dimension of the results is relatively weak. Given the data limitation on the institutional delivery indicator (only available from 1995 onwards), to test whether the quality of institutions remains an important explanatory variable through time, we use a series of proxies for this variable. In particular, three measures of institutional quality are available since 1975: economic complexity, the Chin-Ito openness, and the Fraser Institute Economic Freedom.

Results are reported in table 7. The first column shows the benchmark model. Model (1) replaces our institutional delivery indicator by Economic Complexity index (ECI), model (2) by the Chinn-Ito Financial Openness Index (KAOPEN), model (3) by the Fraser Institute Economic Freedom (EFF), and model (4) by the Heritage Foundation Economic Freedom (EFH). All these indicators are standardised such that higher values represent better institutions and they are centred on the cross country linear average in 1998. 
The ECI is a holistic measure of the production characteristics of countries, which embeds the knowledge accumulated and the country's industrial composition. This information is used to create measures of the relative complexity of a country's exports (Hidalgo and Ricardo, 2009). KAOPEN is a measure of a country's degree of capital account openness (Chinn and Ito, 2006), based on restrictions to cross-border financial transactions. The EFF measures the degree to which the policies and institutions of countries are supportive of economic freedom (Block, 1991). This latter concept is assessed against personal choices, voluntary exchanges, freedom to enter markets and compete, and security of person and privately owned property. The summary index measures the degree of economic freedom in five broad areas: size of government, legal structure and property rights, access to sound money, international trade and regulation of credit, labour and business. The EFH is based on 10 quantitative and qualitative factors measuring: rule of law, limited government, regulatory efficiency and open markets (Miller and Kim, 2016). The first two indicators (ECI and KAOPEN) measure the quality of institutions only indirectly (and in a more narrow sense) via the observed complexity of the economic system or via the extent to which a country is subject to financial transaction costs. Instead the other two indicators are closer proxies of institutional delivery as they attempt to measure the efficiency of economic institutions. The last indicator in table 7 is available only since 1995, i.e. it covers the same time span as institutional delivery.

\section{TABle 7}

Expanding the sample period for the EU 27 countries

15 year average potential GDP growth (in PPP)

\begin{tabular}{|c|c|c|c|c|c|}
\hline Institutions & Baseline & $\begin{array}{l}\text { ECI } \\
\text { (1) }\end{array}$ & $\begin{array}{l}\text { KAOPEN } \\
\text { (2) }\end{array}$ & $\begin{array}{l}\text { EFF } \\
\text { (3) }\end{array}$ & $\begin{array}{c}\text { EFH } \\
\text { (4) }\end{array}$ \\
\hline Catching-up & $\begin{array}{l}-0.589^{* * *} \\
(0.0386)\end{array}$ & $\begin{array}{l}-0.522 * * * \\
(0.0179) \\
\end{array}$ & $\begin{array}{l}-0.538^{* * *} \\
(0.0161) \\
\end{array}$ & $\begin{array}{l}-0.596 * * * \\
(0.0255) \\
\end{array}$ & $\begin{array}{l}-0.519 * * * \\
(0.0264) \\
\end{array}$ \\
\hline Institutions & $\begin{array}{l}0.0951 * * * \\
(0.0317) \\
\end{array}$ & $\begin{array}{l}0.0676^{* *} \\
(0.0321)\end{array}$ & $\begin{array}{l}0.0371 * * * \\
(0.0102) \\
\end{array}$ & $\begin{array}{l}0.0757 * * * \\
(0.0218) \\
\end{array}$ & $\begin{array}{c}0.00445^{*} \\
(0.00238) \\
\end{array}$ \\
\hline$($ Debt $>60)$ & $\begin{array}{l}-0.0394 * \\
(0.0197) \\
\end{array}$ & $\begin{array}{c}0.0230 \\
(0.0326)\end{array}$ & $\begin{array}{c}0.0303 \\
(0.0312) \\
\end{array}$ & $\begin{array}{c}0.0226 \\
(0.0239) \\
\end{array}$ & $\begin{array}{r}0.00215 \\
(0.0248) \\
\end{array}$ \\
\hline $\begin{array}{l}(\text { Debt }>60) \mathrm{x} \\
\text { Institutions }\end{array}$ & $\begin{array}{l}0.131 * * * \\
(0.0283)\end{array}$ & $\begin{array}{c}0.0535 \\
(0.0389)\end{array}$ & $\begin{array}{l}-0.00929 \\
(0.0191)\end{array}$ & $\begin{array}{l}0.0522 * * \\
(0.0206)\end{array}$ & $\begin{array}{l}0.0108 * * * \\
(0.00277)\end{array}$ \\
\hline Constant & $\begin{array}{c}2.127 * * * \\
(0.0988) \\
\end{array}$ & $\begin{array}{l}1.941^{* * *} \\
(0.0448)\end{array}$ & $\begin{array}{l}2.000 * * * \\
(0.0467)\end{array}$ & $\begin{array}{l}2.139 * * * \\
(0.0664)\end{array}$ & $\begin{array}{l}1.941 * * * \\
(0.0694)\end{array}$ \\
\hline Observations & 208 & 454 & 458 & 470 & 200 \\
\hline First observation & 1995 & 1975 & 1975 & 1975 & 1995 \\
\hline R-squared & 0.911 & 0.873 & 0.865 & 0.882 & 0.883 \\
\hline
\end{tabular}

Robust standard errors in parentheses.

$* * * p<0.01, * * p<0.05, * p<0.1$

Table 7 shows that when extending the sample period by 20 years, i.e. advancing the starting date from 1995 to 1975 (models (1) to (3)) the role of institutions remains equally important to explain long-term per capita growth. When compar- 
ing all specifications (i.e. also including model (4)), the significance of the institutional variable is maintained. In models (1) to (3) one can also observe that the significance of the debt threshold dummy and the interaction term is notably reduced. Only in model (3) does the interaction term continue to be significant. Thus, from a longer term perspective, it seems that the quality of institutions matters more than the level of indebtedness and that the $60 \%$ threshold dummy itself does not play a role in explaining per capita long term growth since the 1970s. However, for EFF and EFH, which are a closer proxy of institutional delivery, the interaction term between debt and institutions remains significant. Given the longer time series used in model (1) to (3) it is interesting to test how an augmented version of the models would work. Tables A8 (1-4) in annex 5 report the results of the augmented versions of models (1-4) in table 7 . The inclusion of additional variables follows the same principle used in table 6. Tables A8 (1-4) show that coefficient on institutions continue to be very significant, moreover the interaction term between debt and institutions remains significant together with three additional explanatory variables: trade openness, participation rate and education in most of the specifications. Finally table A12 in annex 7 shows the results for institutional quality as estimated by Kunčić (2014), where the institutional indicator is derived from factor analysis based on 30 available indicators. Even though the magnitude of the coefficients differs due to different scales, the overall message remains broadly unchanged also for this alternative measure of institutional quality.

Overall, the extension of the sample period continues to support the importance of institutions for supporting higher long-term per capita growth. However, the evidence on the importance of debt becomes weaker and the model's specification seems to miss some explanatory variables when we go back to the 1970 s.

\section{ADDITIONAL ROBUSTNESS EXERCISES}

In this section we report three additional robustness exercises to test the validity of our benchmark model. First, we use a variant of the model where the focus is on the interaction between the debt dummy threshold and institutional delivery from the countries which have below average institutional delivery; second, we test the robustness of the results by changing the measures of long-term per capita GDP growth and finally we change the time span of the target variable, per capita GDP growth, from annual to twenty-year average growth to see if the information content of the model changes for short, medium and long term growth.

\subsection{DIFFERENT MEASURES OF PER CAPITA GDP GROWTH AND GDP LEVELS}

Another robustness check consists of assessing the sensitivity of the model (1) to changing the measure of per capita long-term GDP growth. Throughout the paper the baseline measure of per capita long term GDP growth has been the European Commission (EC) estimates of the PPP-adjusted potential GDP per capita. The choice was dictated by the need to consider a trend variable and to correct it for the purchasing power (PPP-adjustment) of the different EU countries. However, given the unobservable status of potential output estimates and the uncertainty 
related to PPP-adjustment estimates some robustness checks on these two parameters are warranted.

The robustness check is carried out by using four alternative measures of longterm per capita GDP growth (table 8).

Actual real GDP PPP-adjusted: in this case the EC PPP-adjusted potential GDP per capita estimates are replaced by actual PPP-adjusted GDP per capita figures (table 8 (1)).

Actual real GDP: in this case the EC PPP-adjusted potential GDP per capita estimates are replaced by real GDP per capita estimates (table $8(2)$ ).

IMF Potential GDP: in this case the EC PPP-adjusted potential GDP per capita estimates are replaced by IMF potential GDP per capita estimates. It should be noted that the IMF doesn't provide the full history for the countries that more recently joined the EU and euro area (table 8 (3)).

Potential GDP relative to the EU average: in this case instead of taking the EC PPP-adjusted potential GDP per capita estimates, we use for the target variable and for the explanatory variable the PPP adjusted GDP per capita relative to the European Union average (table 8 (4)).

\section{TABLE 8}

Different measures of GDP growth and GDP levels

\begin{tabular}{|c|c|c|c|c|c|}
\hline & \multicolumn{5}{|c|}{15 year average per capita GDP growth } \\
\hline & Baseline & $\begin{array}{l}\text { Actual } \\
\text { PPP Log } \\
\text { (1) }\end{array}$ & $\begin{array}{c}\text { Actual } \\
\text { Real Log } \\
\text { (2) }\end{array}$ & $\begin{array}{c}\text { IMF Pot } \\
\text { Real Log } \\
\text { (3) }\end{array}$ & $\begin{array}{c}\text { EC Pot } \\
\text { PPP RelEU } \\
\text { (4) }\end{array}$ \\
\hline PPP Log & $\begin{array}{l}-0.589 * * * \\
(0.0386)\end{array}$ & $\begin{array}{l}-0.597 * * * \\
(0.0441)\end{array}$ & & & \\
\hline Real Log & & & $\begin{array}{l}-0.403 * * * \\
(0.0499)\end{array}$ & $\begin{array}{l}-0.373 * * * \\
(0.0398)\end{array}$ & \\
\hline PPP RelEU & & & & & $\begin{array}{l}-0.469 * * * \\
(0.0509)\end{array}$ \\
\hline Institutions & $\begin{array}{l}0.0951 * * * \\
(0.0317)\end{array}$ & $\begin{array}{l}0.0909 * * \\
(0.0359)\end{array}$ & $\begin{array}{c}0.146 * * \\
(0.0533)\end{array}$ & $\begin{array}{l}0.148 * * * \\
(0.0455)\end{array}$ & $\begin{array}{l}6.432 * * \\
(2.455)\end{array}$ \\
\hline$($ Debt $>60)$ & $\begin{array}{l}-0.0394 * \\
(0.0197)\end{array}$ & $\begin{array}{l}-0.0540^{*} \\
(0.0271)\end{array}$ & $\begin{array}{l}-0.0401 \\
(0.0298)\end{array}$ & $\begin{array}{l}-0.0401 \\
(0.0269)\end{array}$ & $\begin{array}{l}-3.208 \\
(2.002)\end{array}$ \\
\hline $\begin{array}{l}(\text { Debt }>60) \mathrm{x} \\
\text { Institutions }\end{array}$ & $\begin{array}{l}0.131 * * * \\
(0.0283)\end{array}$ & $\begin{array}{l}0.150 * * * \\
(0.0384)\end{array}$ & $\begin{array}{l}0.161 * * * \\
(0.0400)\end{array}$ & $\begin{array}{l}0.144 * * * \\
(0.0327)\end{array}$ & $\begin{array}{l}11.63 * * * \\
(3.237)\end{array}$ \\
\hline Constant & $\begin{array}{l}2.127 * * * \\
(0.0988)\end{array}$ & $\begin{array}{l}2.134 * * * \\
(0.113)\end{array}$ & $\begin{array}{l}1.374 * * * \\
(0.131)\end{array}$ & $\begin{array}{l}1.296^{* * *} \\
(0.101)\end{array}$ & $\begin{array}{l}46.05^{* * *} \\
(4.024)\end{array}$ \\
\hline Observations & 208 & 208 & 208 & 184 & 208 \\
\hline R-squared & 0.911 & 0.896 & 0.799 & 0.766 & 0.776 \\
\hline
\end{tabular}

Robust standard errors in parentheses.

$* * * p<0.01, * * p<0.05, * p<0.1$ 
The results in table 8 show that the regression model (1) is robust to measurement changes of the 15-year average GDP growth. Generally, the catching-up coefficient becomes smaller when using other measures of per capita GDP growth while the institutional delivery coefficient becomes larger. The significance of the debt threshold dummy is somewhat reduced, but the significance of the interaction term remains intact. From these exercises one can conclude that the measurement uncertainty related to "potential" and "PPP-adjustment" does not distort the results.

\subsection{VARYING TIME SPANS AND STARTING LEVELS}

The final robustness check consists of evaluating to what extent the regression results depend on the starting level and on the time span used. This exercise is needed to test if the robustness of the results depends on the chosen sample period, both in terms of starting level used for the regressors and in terms of time span used for GDP growth variable. The robustness check is done by estimating 380 crosssectional equations (19 base years and 20 years of possible time spans) for equation (1) above. In other words, starting at the base year 1996, twenty cross-sectional regressions have been carried out on that base year to explain an average GDP growth that goes from one to 20 years. The results are shown in form of a matrix where the $\mathrm{y}$ axis represents the time span and the $\mathrm{x}$ axis the starting or base year.

Equation (5) modifies model (1) by changing the base year and the time span:

$$
\begin{aligned}
\left(y_{c, t=\text { Base }+ \text { Span }}-y_{c, t=\text { Base }}\right)= & \alpha+\beta_{y} y_{c, t=\text { Base }}+\beta_{D}(D>60)_{c, t=\text { Base }}+\beta_{I} I_{c, t=\text { Base }} \\
& +\beta_{D I}(D>60)_{c, t=\text { Base }} I_{c, t=\text { Base }}+\varepsilon_{c}
\end{aligned}
$$

Table 9 reports the values of the $\mathrm{R}^{2}$ in equation (5). It is possible to observe that the explanatory power of the regression is larger the longer is the time span considered for the average per capita GDP growth. In particular the $\mathrm{R}^{2}$ is relatively higher for average GDP growth rates that include more than 9 years of observations. The matrices with t-statistics of the explanatory variables are reported in annex 6 . They show that the significance of the model is maintained for different base years and time spans, but the performance is better for a longer time-span. Overall this exercise suggests that the model is more suitable to explain long-term growth performances and not the business-cycle frequencies. It also suggests that the model would continue to perform well even when taking a longer time span than the one used in the paper.

Given the above results a few variants of the target variable are considered in table 10. We test how the model performs for three measures of the long-term per capita GDP growth. First, we reduce the overlapping period and assume that we have only three different data points for the 15-year average GDP per capita growth (1996, 1999 and 2002); second, we consider the 23-year average per capita GDP growth and, third, we consider two non-overlapping 10-year average per capita GDP growth periods. These variants imply a significant drop of the availa- 
ble observations and basically the model is reduced to a cross-sectional analysis. This, notwithstanding institutional delivery and its interaction with the debt threshold dummy, remains largely significant.

\section{TABle 9}

$R^{2}$ of equation (5)

Base 1996199719981999200020012002200320042005200620072008200920102011201220132014 Span

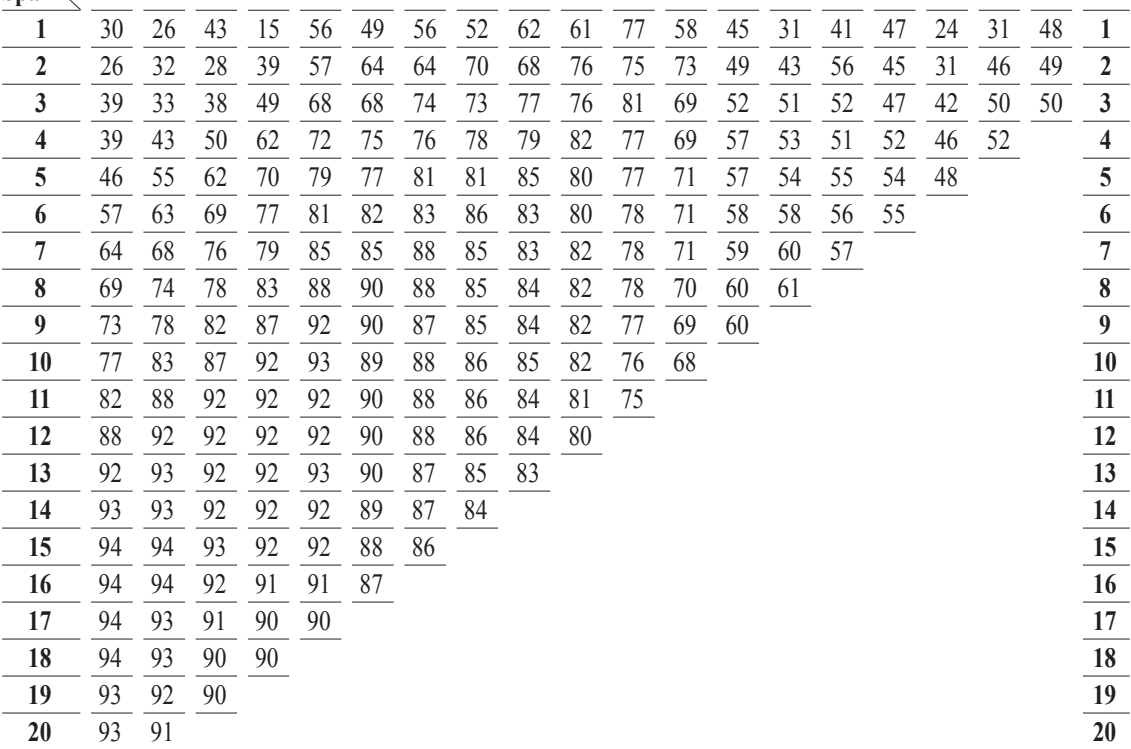

$\overline{1996} \overline{1997} \overline{1998} \overline{1999} \overline{2000} \overline{2001} \overline{2002} \overline{2003} \overline{2004} \overline{2005} \overline{2006} \overline{2007} \overline{2008} \overline{2009} \overline{2010} \overline{2011} \overline{2012} \overline{2013} \overline{2014}$

\section{TABLE 10}

Varying growth spans

Average potential per capita GDP growth (in PPP)

\begin{tabular}{|c|c|c|c|c|}
\hline Outcome & Baseline & $\begin{array}{c}\text { 15yr starting } \\
1996 / 1999 / 2002\end{array}$ & $\begin{array}{c}\text { 23yr starting } \\
1995\end{array}$ & $\begin{array}{c}\text { 10yr } \\
\text { non-overlapping }\end{array}$ \\
\hline Catching-up & $\begin{array}{l}-0.589 * * * \\
(0.0386)\end{array}$ & $\begin{array}{l}-0.572 * * * \\
(0.0430)\end{array}$ & $\begin{array}{l}-0.705^{* * *} \\
(0.0637)\end{array}$ & $\begin{array}{l}-0.471 * * * \\
(0.0378)\end{array}$ \\
\hline Institutions & $\begin{array}{l}0.0951^{* * *} \\
(0.0317) \\
\end{array}$ & $\begin{array}{c}0.0892 * * \\
(0.0359)\end{array}$ & $\begin{array}{c}0.0965^{*} \\
(0.04838)\end{array}$ & $\begin{array}{l}0.127 * * * \\
(0.0304)\end{array}$ \\
\hline$($ Debt $>60)$ & $\begin{array}{l}-0.0394 * \\
(0.0197)\end{array}$ & $\begin{array}{l}-0.0549 * * \\
(0.0239)\end{array}$ & $\begin{array}{l}-0.0153 \\
(0.0380)\end{array}$ & $\begin{array}{l}-0.00512 \\
(0.0226)\end{array}$ \\
\hline $\begin{array}{l}(\text { Debt }>60) \mathrm{x} \\
\text { Institutions }\end{array}$ & $\begin{array}{l}0.131 * * * \\
(0.0283)\end{array}$ & $\begin{array}{l}0.151^{* * *} \\
(0.0354)\end{array}$ & $\begin{array}{l}0.202^{* * *} \\
(0.0483)\end{array}$ & $\begin{array}{r}0.0809^{*} \\
(0.0430)\end{array}$ \\
\hline Constant & $\begin{array}{l}2.127 * * * \\
(0.0988)\end{array}$ & $\begin{array}{l}2.080 * * * \\
(0.108)\end{array}$ & $\begin{array}{l}2.505^{* * *} \\
(0.152)\end{array}$ & $\begin{array}{l}1.674 * * * \\
(0.101)\end{array}$ \\
\hline Observations & 208 & 78 & 25 & 52 \\
\hline R-squared & 0.911 & 0.904 & 0.936 & 0.843 \\
\hline
\end{tabular}

Robust standard errors in parentheses.

$* * * p<0.01, * * p<0.05, * p<0.1$ 
Finally, table 11 reports three cross-sectional results. The first is the one already presented in table 10, where the 23 year average per capita potential growth (from 1995 until 2017) is regressed against the level of GDP per capita, the quality of institutions, the debt threshold and the interaction term. The second and the third replace the institutional delivery with the Fraser Institute Economic Freedom Index (EFI) described in section 6, which is available for a limited group of EU countries since the mid-1970s. In the second column, the results with the EFI are shown for the 23 year average potential per capita growth. This is done to show that the cross-sectional results are not significantly affected by the choice of the institutional indicator. In the third column, the results with the EFI are shown for the 35-year average per capita potential growth. While the very limited number of observations does not allow a robust conclusion to be derived, the results continue to be consistent with the view that the quality of institutions is an important determinant of long-term growth.

\section{TABLE 11}

Cross-sectional results

Average potential per capita GDP growth (in PPP)

\begin{tabular}{|c|c|c|c|}
\hline Outcome & $\begin{array}{c}\text { 23yr starting } 1995 \\
\text { (Institutional delivery) }\end{array}$ & $\begin{array}{c}\text { 23yr starting } 1995 \\
\text { (EFI) }\end{array}$ & $\begin{array}{l}35 y r \text { starting } \\
\text { in } 1983 \text { (EFI) }\end{array}$ \\
\hline Catching-up & $\begin{array}{l}-0.705^{* * *} \\
(0.0637)\end{array}$ & $\begin{array}{l}-0.664 * * * \\
(0.0514)\end{array}$ & $\begin{array}{l}-0.738^{* * *} \\
(0.2122)\end{array}$ \\
\hline Institutions & $\begin{array}{l}0.0965^{*} \\
(0.0484)\end{array}$ & $\begin{array}{c}0.0318 \\
(0.0233)\end{array}$ & $\begin{array}{l}0.165^{* * *} \\
(0.0473)\end{array}$ \\
\hline$($ Debt $>60)$ & $\begin{array}{l}-0.0153 \\
(0.0380)\end{array}$ & $\begin{array}{l}-0.0155 \\
(0.0402)\end{array}$ & $\begin{array}{c}0.0438 \\
(0.0896)\end{array}$ \\
\hline $\begin{array}{l}(\text { Debt }>60) x \\
\text { Institutions }\end{array}$ & $\begin{array}{l}0.202 * * * \\
(0.0483)\end{array}$ & $\begin{array}{l}0.197 * * * \\
(0.037)\end{array}$ & $\begin{array}{l}-0.0847 \\
(0.0862)\end{array}$ \\
\hline Constant & $\begin{array}{l}2.505^{* * *} \\
(0.152)\end{array}$ & $\begin{array}{l}2.423^{* * * *} \\
(0.135)\end{array}$ & $\begin{array}{l}2.662 * * * \\
(0.4835)\end{array}$ \\
\hline Observations & 25 & 25 & 13 \\
\hline R-squared & 0.936 & 0.943 & 0.768 \\
\hline
\end{tabular}

Robust standard errors in parentheses.

$* * * p<0.01, * * p<0.05, * p<0.1$

\section{CONCLUSIONS}

This paper tried to explain the different long-term per capita GDP growth performances in Europe by using a parsimonious empirical model, testing if and how the initial quality of institutions and government debt are important determinants of long term growth in Europe. The benchmark model explains long-term growth by the initial levels of government debt, quality of institutions (institutional delivery) and an interaction term between the two variables, on top of the initial level of GDP per capita (to account for the catching-up potential). The sample period used for the initial level of variables runs from 1995 to 2002, while long term per capita growth is the 15-year average potential per capita GDP growth estimated by the Commission. 
The benchmark model is estimated for the whole of Europe, the OECD and for two groups of countries: countries with fixed exchange rate regimes and belonging to the monetary union, and countries with flexible exchange rate regimes. The findings of the paper support the view that the quality of institutions is an important determinant of long-term growth. The results seem particularly important for countries where institutional delivery is below or around the EU average and initial public debt is above the threshold of, for example, 60 or $70 \%$. Such countries could experience significantly higher per capita GDP growth if their institutions were improved. Interestingly, initial debt levels above $60 \%$ or $70 \%$ appear not to be negative for long-term growth in the presence of very sound institutions. While this result needs to be treated carefully as it is driven by rather few observations, it might suggest that thresholds above which debt levels are detrimental for growth are not the same across countries, but could to be endogenous to the quality of public institutions.

While the results hold across different groups of countries, it appears that the conditions for real convergence are generally also good for the group of euro area and fixed exchange rate countries. At the same time the quality of institutions might be particularly important for this group. This could reflect that sound institutions and the associated policies - are helpful to compensate for the lack of the exchange rate tool as adjustment and disciplinary device, supporting the view that improvements in institutions and structural reforms are particularly important for euro area countries to be able to reap the full benefits of monetary union. However, this result is preliminary and requires further research.

The benchmark model is changed in several ways to check the validity of the results. First the results are assessed against different debt thresholds (corresponding to the EU average, the Maastricht threshold and the EA average); second the model is augmented with different control variables, which are typically included in the growth literature (education attainment, saving rate, government expenditure, etc.); third other measures of institutional quality are used as a proxy for institutional delivery, which allow the sample period considered to be extended by 20 years, i.e. moving the starting date from 1995 to 1975 . These changes continue to support the evidence that institutional delivery is a critical determinant of longterm growth in Europe; however the significance of debt thresholds turns out to be less robust to the above changes.

Finally other robustness exercises are reported by using different measures of long-term growth and different time-spans. Also these exercises show that the estimates obtained with the benchmark model are relatively robust to changes in specifications. The only variable where we observe a drop in significance is the debt dummy. This suggests that debt per se is not a problem but can become a problem in the presence of weak institutions. 
There are of course many factors which are not or only partially included in the institutional variables used here, which can enhance longer-term growth. These might include macroeconomic stability, sound fiscal policies, efficient education systems and incentives for investment in human and real capital, a high degree of flexibility and openness in product and labour markets, well capitalised and supervised financial institutions, efficient insolvency frameworks, conditions for an efficient use of capital and labour, including via higher economic integration within the EU and a more active use of national policy tools to prevent asset price and credit boom-bust cycles. The results of this paper are broadly consistent with the view that the World Bank (or other) indicators measuring the quality of institutions cover key factors and mechanisms, which also determine the probability that governments and societies in the future support policies and reforms in the above areas, enhancing long-term growth. The link between institutional quality and the probability of the above mentioned sound policies and reforms that enhance longterm growth has however not been tested explicitly. It is left for further research.

\section{Disclosure statement}

No potential conflict of interest was reported by the authors. 
ANNEX 1

\section{ANALYSIS OF THE EVOLUTION OF THE INSTITUTIONAL DELIVERY INDICATORS OVER TIME}

This annex looks at the evolution of the institutional delivery indicators over time. The analysis is done by using the difference in difference approach, where the 28 EU countries have been divided in five groups defined as follows:

- Early EA-high: the early euro area joiners with the WGI in 1996 > 1.33

- Early EA-low: the early euro area joiners with the WGI in $1996<1.33$

- New EA: the countries that joined the EA after 2001

- NOEA-high: the countries not part of the EA with WGI in 1996 > 1.33

- NOEA-low: the countries not part of the EA with WGI in $1996<1.33$

The breakpoint of 1.33 was decided upon using a difference in difference calculation, where this cut off reached the highest $\mathrm{R}^{2}$.

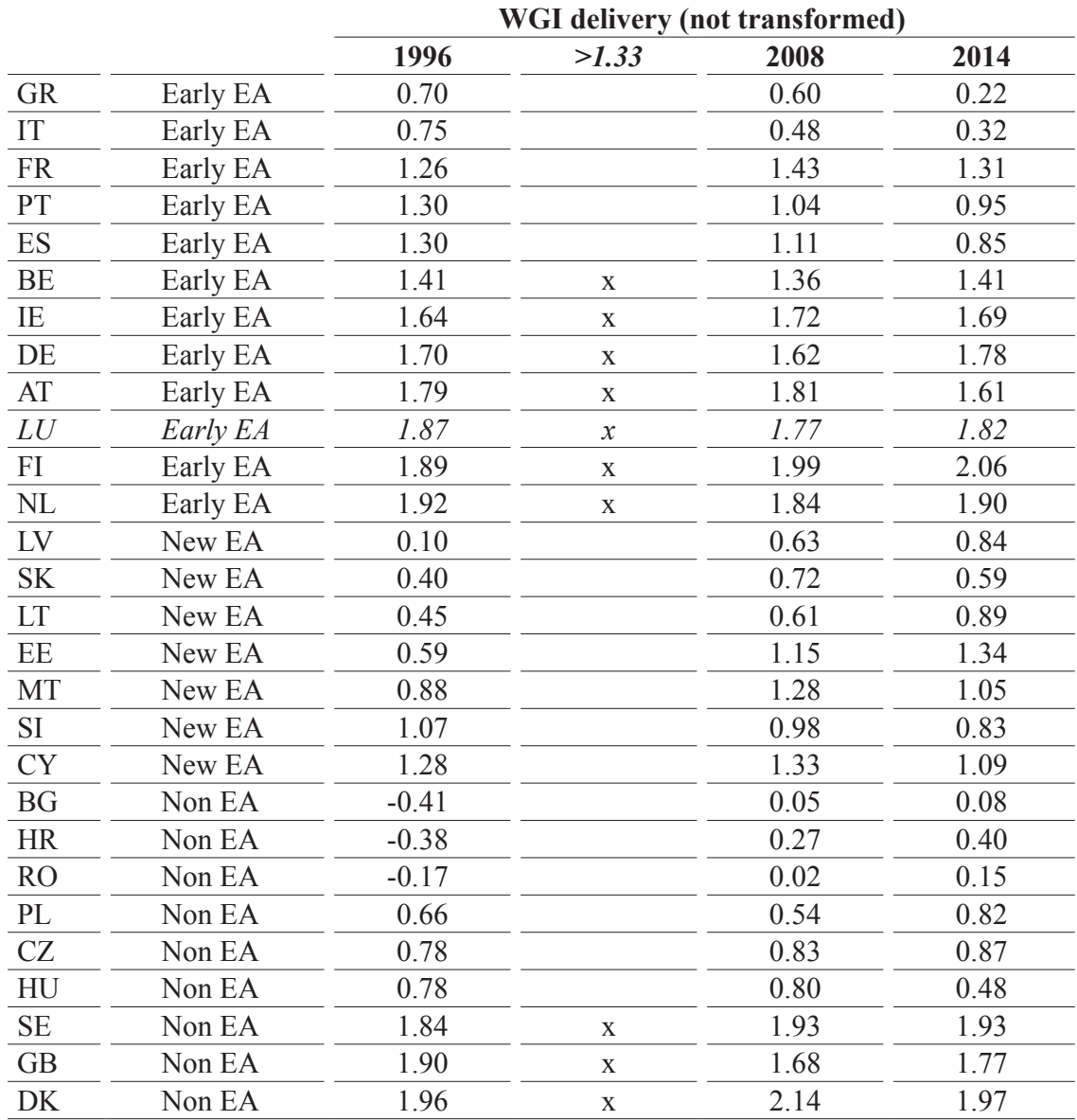

The charts below show the country group mean development of WGI-delivery over time (red line) and the linear fits split into three intervals: 1996-2001, 2002-2008 and 2009-2014. The first row shows absolute values, the second row allows for group fixed effects in 1996 and the last row allows for country fixed effects in 1996. 

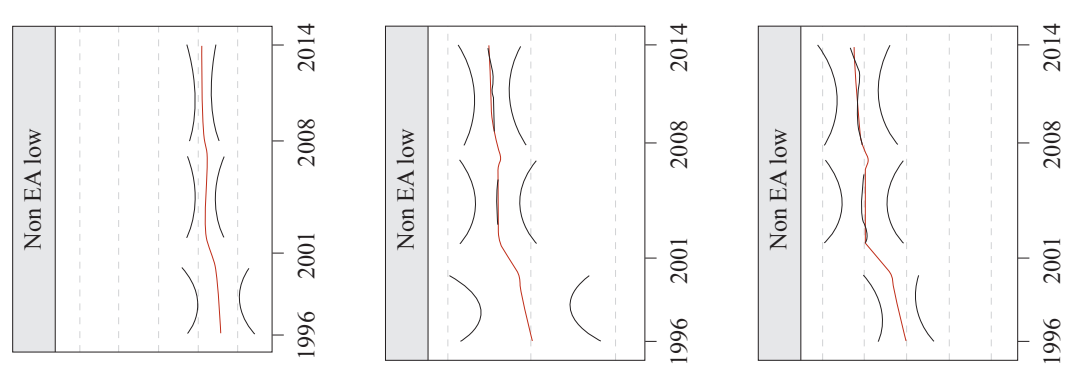

189
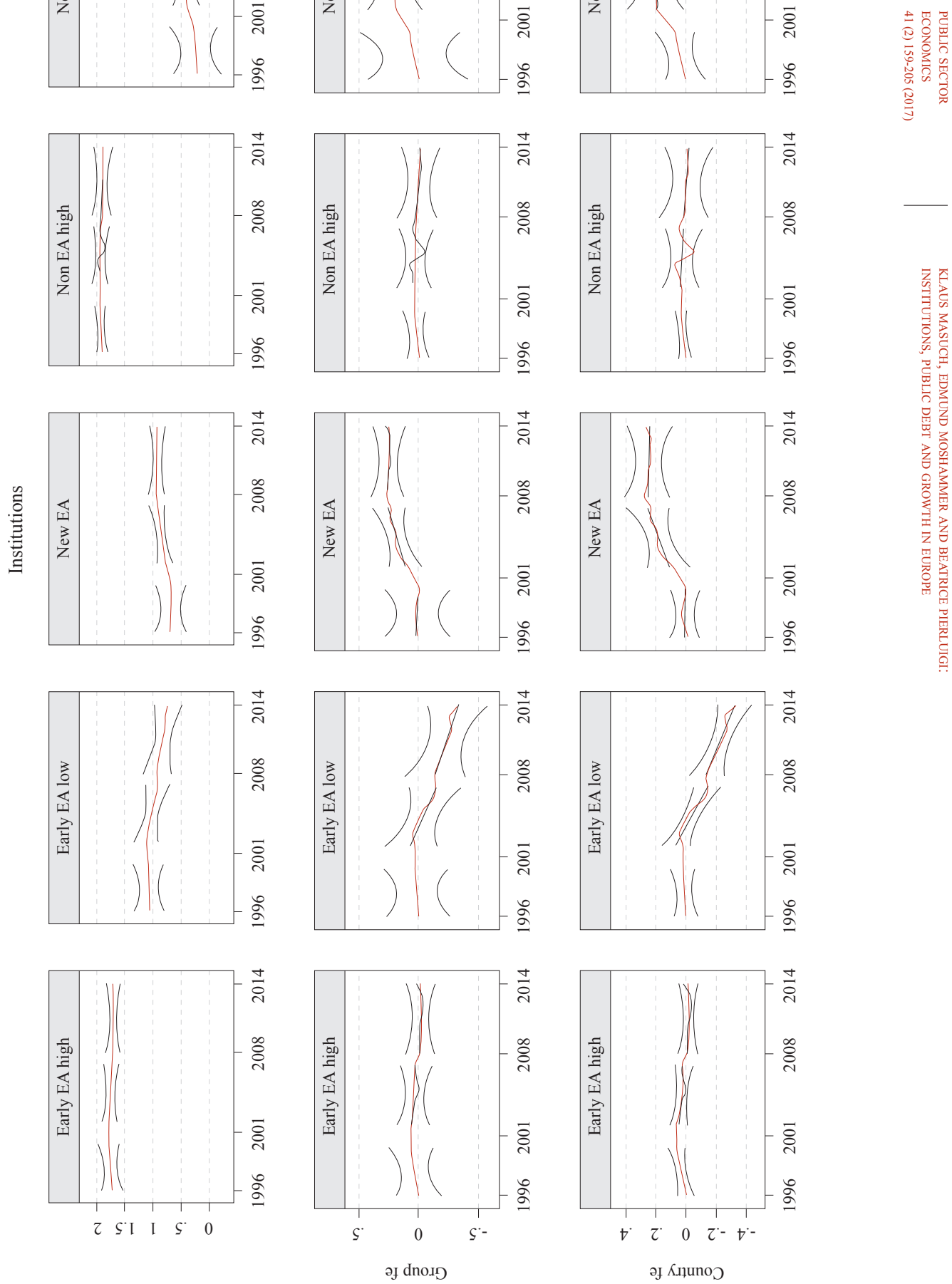
ANNEX 2

\section{GENERAL GOVERNMENT DEBT}

The table below shows the General Government Debt in percent of GDP. Countries are ordered by debt level in 1999 . Values larger than $60 \%$ formatted in bold.

\begin{tabular}{|c|c|c|c|c|c|c|c|c|}
\hline & 1996 & 1997 & 1998 & 1999 & 2000 & 2001 & 2008 & 2014 \\
\hline $\mathrm{BE}$ & 128.0 & 123.2 & 118.2 & 114.4 & 108.8 & 107.6 & 92.4 & 106.7 \\
\hline IT & 116.3 & 113.7 & 110.8 & 109.6 & 105.1 & 104.7 & 102.3 & 132.3 \\
\hline GR & 101.2 & 99.3 & 97.2 & 98.6 & 104.7 & 106.8 & 109.4 & 178.6 \\
\hline BG & & 97.3 & 69.3 & 76.1 & 71.2 & 64.7 & 13.0 & 27.0 \\
\hline AT & 68.0 & 63.2 & 63.6 & 66.4 & 65.9 & 66.5 & 68.5 & 84.2 \\
\hline MT & 38.7 & 46.6 & 51.2 & 62.1 & 60.9 & 65.5 & 62.7 & 66.9 \\
\hline $\mathrm{SE}$ & 70.3 & 68.2 & 66.7 & 61.5 & 50.6 & 51.7 & 36.8 & 44.9 \\
\hline ES & 65.6 & 64.4 & 62.5 & 60.9 & 58.0 & 54.2 & 39.4 & 99.3 \\
\hline FR & 59.7 & 61.1 & 61.0 & 60.2 & 58.7 & 58.2 & 68.1 & 95.6 \\
\hline DE & 57.6 & 58.8 & 59.4 & 60.0 & 58.9 & 57.7 & 65.0 & 74.9 \\
\hline $\mathrm{HU}$ & 71.6 & 62.1 & 60.0 & 59.9 & 55.1 & 51.7 & 71.6 & 76.2 \\
\hline NL & 71.2 & 65.6 & 62.5 & 58.2 & 51.4 & 48.7 & 54.5 & 68.2 \\
\hline $\mathrm{DK}$ & 69.9 & $\begin{array}{l}65.8 \\
\end{array}$ & 61.8 & 58.2 & 52.4 & 48.5 & 33.4 & 44.6 \\
\hline CY & 49.2 & 53.2 & 54.8 & 55.1 & 55.1 & 56.9 & 45.1 & 108.2 \\
\hline PT & 59.5 & 55.2 & 51.8 & 51.0 & 50.3 & 53.4 & 71.7 & 130.2 \\
\hline SK & 30.5 & 33.0 & 33.9 & 47.1 & 49.6 & 48.3 & 28.2 & 53.5 \\
\hline IE & 69.9 & 61.6 & 51.5 & 46.7 & 36.1 & 33.2 & 42.4 & 107.5 \\
\hline FI & 55.3 & 52.2 & 46.9 & 44.1 & 42.5 & 41.0 & 32.7 & 59.3 \\
\hline GB & 47.8 & 46.6 & 44.0 & 41.7 & 38.9 & 36.0 & 51.7 & 88.2 \\
\hline PL & 42.4 & 42.3 & 38.4 & 39.0 & 36.5 & 37.3 & 46.6 & 50.4 \\
\hline SI & 21.6 & 22.1 & 22.8 & 23.7 & 25.9 & 26.1 & 21.6 & 80.8 \\
\hline LT & 13.9 & 15.4 & 16.5 & 22.7 & 23.5 & 22.9 & 14.6 & 40.7 \\
\hline $\mathrm{RO}$ & 10.6 & 14.9 & 16.7 & 21.6 & 22.4 & 25.7 & 13.2 & 39.8 \\
\hline $\mathrm{CZ}$ & 11.6 & 12.1 & 13.9 & 15.2 & 17.0 & 22.8 & 28.7 & 42.7 \\
\hline LV & 13.3 & 10.7 & 9.0 & 12.1 & 12.1 & 13.9 & 18.7 & 40.8 \\
\hline EE & 7.5 & 7.0 & 6.0 & 6.5 & 5.1 & 4.8 & 4.5 & 10.4 \\
\hline LU & 7.6 & 7.5 & 7.2 & 6.4 & 7.6 & 6.6 & 14.4 & 23.0 \\
\hline HR & & & & & & 36.1 & 38.9 & 85.1 \\
\hline EA19 & 72.7 & 72.2 & 71.7 & 70.6 & 68.0 & 67.0 & 68.5 & 94.5 \\
\hline EU28 & & & & & & 59.8 & 61.0 & 88.6 \\
\hline
\end{tabular}




\section{SLS ESTIMATES}

This instrumental variable approach requires that the instruments (legal origin) are relevant, i.e. they are correlated with the explanatory variable (institutions) and exogenous, i.e. they are not correlated with the error term in our regression of interest. In our baseline regression institutions appear both independently and in interaction with the debt $>60$ dummy. It can be argued that if legal origin is a valid instrument for institutions, then legal origins in interaction with the exogenous debt dummy is also a valid instrument for institutions interacting with the debt dummy. The relevance of the instruments used can be tested by checking if the F-statistic of the first stage is larger than 10. As shown in table A2 below this criterion is met with ease if we don't enforce cluster-robust standard errors however the criterion is not met for the more robust approach.

\section{TABLe A2}

First stage of 2SLS regression shown in table 2

\begin{tabular}{|c|c|c|c|c|}
\hline $\begin{array}{l}\text { Explanatory } \\
\text { variables }\end{array}$ & Institutions & $\begin{array}{l}(\text { Debt }>60) x \\
\text { Institutions }\end{array}$ & Institutions & $\begin{array}{l}(\text { Debt }>60) x \\
\text { Institutions }\end{array}$ \\
\hline$($ Origin$=$ English $)$ & Omitted & Omitted & Omitted & Omitted \\
\hline$($ Debt $>60) \times($ Origin $=$ English $)$ & Omitted & Omitted & Omitted & Omitted \\
\hline (Origin=French) & $\begin{array}{l}-0.127 \\
(0.0809)\end{array}$ & $\begin{array}{c}0.0200 \\
(0.0626)\end{array}$ & $\begin{array}{l}-0.127 \\
(0.165)\end{array}$ & $\begin{array}{c}0.0200 \\
(0.0248)\end{array}$ \\
\hline (Origin $=$ Soviet) & $\begin{array}{l}-0.414 * * * \\
(0.0895)\end{array}$ & $\begin{array}{c}0.115^{*} \\
(0.0693)\end{array}$ & $\begin{array}{l}-0.414 * * \\
(0.190) \\
\end{array}$ & $\begin{array}{c}0.115 \\
(0.0781)\end{array}$ \\
\hline (Origin $=$ German $)$ & $\begin{array}{r}0.0689 \\
(0.115)\end{array}$ & $\begin{array}{l}-0.00983 \\
(0.0893)\end{array}$ & $\begin{array}{r}0.0689 \\
(0.143)\end{array}$ & $\begin{array}{l}-0.00983 \\
(0.0153)\end{array}$ \\
\hline (Origin=Scandinavian) & $\begin{array}{l}0.332 * * * \\
(0.0900)\end{array}$ & $\begin{array}{l}-0.0151 \\
(0.0697)\end{array}$ & $\begin{array}{l}0.332 * \\
(0.163)\end{array}$ & $\begin{array}{l}-0.0151 \\
(0.0199)\end{array}$ \\
\hline$($ Debt $>60)$ & $\begin{array}{r}0.0384 \\
(0.144)\end{array}$ & $\begin{array}{l}0.521 * * * \\
(0.112)\end{array}$ & $\begin{array}{c}0.0384 \\
(0.194)\end{array}$ & $\begin{array}{l}0.521 * * * \\
(0.157)\end{array}$ \\
\hline$($ Debt $>60) \times($ Origin $=$ French $)$ & $\begin{array}{l}-0.289^{*} \\
(0.160)\end{array}$ & $\begin{array}{l}-0.392 * * * \\
(0.124)\end{array}$ & $\begin{array}{l}-0.289 \\
(0.238)\end{array}$ & $\begin{array}{l}-0.392^{*} \\
(0.224)\end{array}$ \\
\hline$($ Debt $>60) \times($ Origin $=$ Soviet $)$ & $\begin{array}{l}-0.0295 \\
(0.171)\end{array}$ & $\begin{array}{l}-1.214 * * * \\
(0.133)\end{array}$ & $\begin{array}{l}-0.0295 \\
(0.296)\end{array}$ & $\begin{array}{l}-1.214 * * * \\
(0.360)\end{array}$ \\
\hline$($ Debt $>60) \times($ Origin $=$ German $)$ & $\begin{array}{l}-0.00134 \\
(0.196)\end{array}$ & $\begin{array}{l}0.253^{*} \\
(0.152)\end{array}$ & $\begin{array}{l}-0.00134 \\
(0.194)\end{array}$ & $\begin{array}{c}0.253 \\
(0.158)\end{array}$ \\
\hline $\begin{array}{l}(\text { Debt }>60) x \\
\text { (Origin=Scandinavian) }\end{array}$ & $\begin{array}{l}-0.0884 \\
(0.181)\end{array}$ & $\begin{array}{l}0.374 * * * \\
(0.141)\end{array}$ & $\begin{array}{l}-0.0884 \\
(0.212)\end{array}$ & $\begin{array}{l}0.374 * * \\
(0.165) \\
\end{array}$ \\
\hline Catching-up & $\begin{array}{l}0.782 * * * \\
(0.0694)\end{array}$ & $\begin{array}{c}0.133 * * \\
(0.0537)\end{array}$ & $\begin{array}{l}0.782 * * * \\
(0.155)\end{array}$ & $\begin{array}{l}0.133 \\
(0.0867)\end{array}$ \\
\hline Constant & $\begin{array}{l}-1.782 * * * \\
(0.216)\end{array}$ & $\begin{array}{l}-0.401 * * \\
(0.168)\end{array}$ & $\begin{array}{l}-1.782 * * * \\
(0.487)\end{array}$ & $\begin{array}{l}-0.401 \\
(0.261)\end{array}$ \\
\hline Observations & 208 & 208 & 208 & 208 \\
\hline R-squared & 0.843 & 0.691 & 0.843 & 0.691 \\
\hline Clustered standard errors & $\mathrm{NO}$ & NO & YES & YES \\
\hline F-stat of excluded instruments & 14.41 & 37.86 & 5.354 & 9.282 \\
\hline
\end{tabular}

Robust standard errors in parentheses.

$* * * p<0.01, * * p<0.05, * p<0.1$ 
TABLE A3

Changing the country coverage (2SLS)

\begin{tabular}{|c|c|c|c|c|}
\hline & $\begin{array}{l}\text { EU } \\
(27)\end{array}$ & $\begin{array}{c}\text { EU + other OECD } \\
(\mathbf{3 3})\end{array}$ & $\begin{array}{l}\text { Fixed ER } \\
\text { (21) }\end{array}$ & $\begin{array}{c}\text { Flexible ER } \\
\text { (12) }\end{array}$ \\
\hline Log GDP (PPP) & $\begin{array}{l}-0.611 * * * \\
(0.0413)\end{array}$ & $\begin{array}{l}-0.624 * * * \\
(0.0654)\end{array}$ & $\begin{array}{l}-0.567 * * * \\
(0.0560)\end{array}$ & $\begin{array}{l}-0.568 * * * \\
(0.0810)\end{array}$ \\
\hline Institutions & $\begin{array}{l}0.116^{* * *} \\
(0.0394)\end{array}$ & $\begin{array}{c}0.159 * * \\
(0.0784)\end{array}$ & $\begin{array}{c}0.0626 \\
(0.0508)\end{array}$ & $\begin{array}{c}0.163 * \\
(0.0866)\end{array}$ \\
\hline$($ Debt $>60)$ & $\begin{array}{l}-0.0357^{*} \\
(0.0186)\end{array}$ & $\begin{array}{l}-0.0612 * * \\
(0.0252)\end{array}$ & $\begin{array}{l}-0.0611^{*} \\
(0.0321)\end{array}$ & $\begin{array}{l}-0.0693 * \\
(0.0383)\end{array}$ \\
\hline $\begin{array}{l}(\text { Debt }>60) \mathrm{x} \\
\text { Institutions }\end{array}$ & $\begin{array}{l}0.123 * * * \\
(0.0289)\end{array}$ & $\begin{array}{c}0.106^{* *} \\
(0.0499)\end{array}$ & $\begin{array}{c}0.131^{* * *} \\
(0.0386)\end{array}$ & $\begin{array}{c}0.0371 \\
(0.0706)\end{array}$ \\
\hline Constant & $\begin{array}{l}2.181^{* * *} \\
(0.105)\end{array}$ & $\begin{array}{l}2.219^{* * *} \\
(0.173)\end{array}$ & $\begin{array}{l}2.067 * * * \\
(0.137)\end{array}$ & $\begin{array}{l}2.087 * * * \\
(0.238)\end{array}$ \\
\hline Observations & 208 & 246 & 160 & 86 \\
\hline R-squared & 0.910 & 0.842 & 0.874 & 0.803 \\
\hline
\end{tabular}

Robust standard errors in parentheses.

$* * * p<0.01, * * p<0.05, * p<0.1$

Other OECD: CA, IS, JP, NO, TR, US.

Flexible ER: CZ, GB, HU, PL, RO, SE, CA, IS, JP, NO, TR, US.

Fixed ER (early EA and fixed exchange rate and late EA joining countries): $C Y, E E, L T, L V, M T$, SI, $S K, B G, D K, H R$.

TABLE A4

Changing debt thresholds (2SLS) - baseline sample EU27

15 year average potential GDP growth (in PPP)

\begin{tabular}{|c|c|c|c|c|}
\hline Debt threshold & $\begin{array}{c}\mathbf{T}=\mathbf{6 0} \\
\text { Baseline }\end{array}$ & $\mathbf{T}=\mathbf{5 0}$ & $T=70$ & $\begin{array}{l}\text { No threshold debt } \\
\text { centred at } 60 \% \text { for } \\
\text { the interaction term }\end{array}$ \\
\hline Log GDP (PPP) & $\begin{array}{l}-0.611 * * * \\
(0.0413)\end{array}$ & $\begin{array}{l}-0.590^{* * *} \\
(0.0494)\end{array}$ & $\begin{array}{l}-0.633^{* * *} \\
(0.0422)\end{array}$ & $\begin{array}{l}-0.556^{* * *} \\
(0.0499)\end{array}$ \\
\hline Institutions & $\begin{array}{l}0.116^{* * *} \\
(0.0394)\end{array}$ & $\begin{array}{c}0.0932 * \\
(0.0503)\end{array}$ & $\begin{array}{c}0.151 * * * \\
(0.0386) \\
\end{array}$ & $\begin{array}{l}0.157 * * * \\
(0.0366)\end{array}$ \\
\hline$($ Debt $>T)$ & $\begin{array}{l}-0.0357 * \\
(0.0186)\end{array}$ & $\begin{array}{l}-0.0641 * * * \\
(0.0235)\end{array}$ & $\begin{array}{l}-0.0175 \\
(0.0252)\end{array}$ & $\begin{array}{l}-0.000419 \\
(0.000475)\end{array}$ \\
\hline $\begin{array}{l}(\text { Debt }>T) x \\
\text { Institutions }\end{array}$ & $\begin{array}{l}0.123 * * * \\
(0.0289)\end{array}$ & $\begin{array}{l}0.133 * * * \\
(0.0363)\end{array}$ & $\begin{array}{l}0.120^{* * *} \\
(0.0393)\end{array}$ & $\begin{array}{l}0.00316^{* * *} \\
(0.00111)\end{array}$ \\
\hline Constant & $\begin{array}{l}2.181 * * * \\
(0.105)\end{array}$ & $\begin{array}{l}2.140^{* * *} \\
(0.123)\end{array}$ & $\begin{array}{l}2.238^{* * *} \\
(0.108)\end{array}$ & $\begin{array}{l}2.012 * * * \\
(0.129)\end{array}$ \\
\hline Observations & 208 & 208 & 208 & 208 \\
\hline R-squared & 0.910 & 0.925 & 0.899 & 0.917 \\
\hline
\end{tabular}

Robust standard errors in parentheses.

$* * * p<0.01, * * p<0.05, * p<0.1$ 
TABLE A5

Expanding the original model (2SLS) - baseline sample EU27

15 year average potential GDP growth (in PPP)

\begin{tabular}{|c|c|c|c|c|c|c|c|}
\hline Catching-up & $\begin{array}{l}-0.611 * * * \\
(0.0413)\end{array}$ & $\begin{array}{l}-0.617 * * * \\
(0.0434)\end{array}$ & $\begin{array}{l}-0.602 * * * \\
(0.0438)\end{array}$ & $\begin{array}{l}-0.561^{* * *} \\
(0.0568)\end{array}$ & $\begin{array}{l}-0.591 * * * \\
(0.0505)\end{array}$ & $\begin{array}{l}-0.570 * * * \\
(0.0544)\end{array}$ & $\begin{array}{l}-0.594 * * * \\
(0.0640)\end{array}$ \\
\hline Institutions & $\begin{array}{l}0.116^{* * *} \\
(0.0394) \\
\end{array}$ & $\begin{array}{c}0.123^{* * *} \\
(0.0408) \\
\end{array}$ & $\begin{array}{r}0.117^{* *} \\
(0.0531) \\
\end{array}$ & $\begin{array}{r}0.0775^{*} \\
(0.0430) \\
\end{array}$ & $\begin{array}{c}0.0954^{*} \\
(0.0540) \\
\end{array}$ & $\begin{array}{l}0.0970^{* *} \\
(0.0440) \\
\end{array}$ & $\begin{array}{c}0.116^{*} \\
(0.0636)\end{array}$ \\
\hline$($ Debt $>60)$ & $\begin{array}{l}-0.0357^{*} \\
(0.0186)\end{array}$ & $\begin{array}{l}-0.0315^{*} \\
(0.0182)\end{array}$ & $\begin{array}{l}-0.0285 \\
(0.0212)\end{array}$ & $\begin{array}{l}-0.0462^{* *} \\
(0.0198)\end{array}$ & $\begin{array}{l}-0.0277 \\
(0.0208)\end{array}$ & $\begin{array}{l}-0.0265 \\
(0.0239)\end{array}$ & $\begin{array}{l}-0.000569 \\
(0.0232)\end{array}$ \\
\hline $\begin{array}{l}(\text { Debt }>60) \mathrm{x} \\
\text { Institutions }\end{array}$ & $\begin{array}{l}0.123 * * * \\
(0.0289)\end{array}$ & $\begin{array}{l}0.122 * * * \\
(0.0298)\end{array}$ & $\begin{array}{l}0.129 * * * \\
(0.0265)\end{array}$ & $\begin{array}{l}0.120^{* * *} \\
(0.0245)\end{array}$ & $\begin{array}{l}0.115 * * * \\
(0.0287)\end{array}$ & $\begin{array}{l}0.0988^{* * *} \\
(0.0331)\end{array}$ & $\begin{array}{l}0.0817 * * * \\
(0.0290)\end{array}$ \\
\hline $\begin{array}{l}\text { Trade } \\
\text { openness }\end{array}$ & & $\begin{array}{c}0.0342 \\
(0.0370)\end{array}$ & & & & & $\begin{array}{c}0.0304 \\
(0.0330)\end{array}$ \\
\hline $\begin{array}{l}\text { Government } \\
\text { expenditure }\end{array}$ & & & $\begin{array}{l}-0.101 \\
(0.135) \\
\end{array}$ & & & & $\begin{array}{l}-0.135 \\
(0.140)\end{array}$ \\
\hline Savings rate & & & & $\begin{array}{l}-0.00151 \\
(0.00174)\end{array}$ & & & $\begin{array}{c}0.00216 \\
(0.00242)\end{array}$ \\
\hline $\begin{array}{l}\text { Participation } \\
\text { rate }\end{array}$ & & & & & $\begin{array}{c}0.00198 \\
(0.00291)\end{array}$ & & $\begin{array}{c}0.00253 \\
(0.00318)\end{array}$ \\
\hline Education & & & & & & $\begin{array}{c}0.00127 \\
(0.000785)\end{array}$ & $\begin{array}{r}0.00162 * * \\
(0.000710)\end{array}$ \\
\hline Constant & $\begin{array}{l}2.181 * * * \\
(0.105)\end{array}$ & $\begin{array}{l}2.046 * * * \\
(0.182)\end{array}$ & $\begin{array}{l}2.072 * * * \\
(0.115)\end{array}$ & $\begin{array}{l}2.071^{* * *} \\
(0.132)\end{array}$ & $\begin{array}{l}1.991 * * * \\
(0.311)\end{array}$ & $\begin{array}{l}2.077 * * * \\
(0.141)\end{array}$ & $\begin{array}{l}1.687^{* * *} \\
(0.228)\end{array}$ \\
\hline Observations & 208 & 208 & 208 & 195 & 208 & 173 & 166 \\
\hline R-squared & 0.910 & 0.913 & 0.913 & 0.925 & 0.912 & 0.896 & 0.919 \\
\hline
\end{tabular}

Robust standard errors in parentheses.

$* * * p<0.01, * * p<0.05, * p<0.1$

\section{TABLE A6}

Expanding the sample period with different institutional indicators (2SLS)

15 year average potential GDP growth (in PPP)

\begin{tabular}{|c|c|c|c|c|c|}
\hline Institutions & $\begin{array}{c}\text { WGI } \\
\text { Baseline }\end{array}$ & $\begin{array}{l}\text { Economic } \\
\text { Complexity }\end{array}$ & $\begin{array}{l}\text { Chinn-Ito } \\
\text { Openness }\end{array}$ & $\begin{array}{c}\text { Economic } \\
\text { Freedom } \\
\text { Fraser }\end{array}$ & $\begin{array}{l}\text { Economic } \\
\text { Freedom } \\
\text { Heritage }\end{array}$ \\
\hline Catching-up & $\begin{array}{l}-0.611 * * * \\
(0.0413)\end{array}$ & $\begin{array}{l}-0.559^{* * *} \\
(0.0306)\end{array}$ & $\begin{array}{l}-0.690 * * * \\
(0.0776)\end{array}$ & $\begin{array}{l}-0.773 * * * \\
(0.0870)\end{array}$ & $\begin{array}{l}-0.516^{* * *} \\
(0.0794)\end{array}$ \\
\hline Institutions & $\begin{array}{l}0.116^{* * *} \\
(0.0394)\end{array}$ & $\begin{array}{l}0.134 * * * \\
(0.0464)\end{array}$ & $\begin{array}{l}0.144 * * * \\
(0.0487)\end{array}$ & $\begin{array}{c}0.202 * * \\
(0.0848)\end{array}$ & $\begin{array}{c}0.00375 \\
(0.00889)\end{array}$ \\
\hline$($ Debt $>60)$ & $\begin{array}{l}-0.0357 * \\
(0.0186)\end{array}$ & $\begin{array}{c}0.0235 \\
(0.0428)\end{array}$ & $\begin{array}{c}0.0358 \\
(0.0292)\end{array}$ & $\begin{array}{c}0.0189 \\
(0.0298)\end{array}$ & $\begin{array}{l}0.000462 \\
(0.0459)\end{array}$ \\
\hline $\begin{array}{l}(\text { Debt }>60) \mathrm{x} \\
\text { Institutions }\end{array}$ & $\begin{array}{c}0.123 * * * \\
(0.0289)\end{array}$ & $\begin{array}{c}0.0875 \\
(0.0697)\end{array}$ & $\begin{array}{l}-0.0569 \\
(0.0682)\end{array}$ & $\begin{array}{r}0.115^{* *} \\
(0.0501)\end{array}$ & $\begin{array}{l}0.0122 * * * \\
(0.00308)\end{array}$ \\
\hline Constant & $\begin{array}{l}2.181^{* * * *} \\
(0.105)\end{array}$ & $\begin{array}{l}2.019 * * * \\
(0.0696)\end{array}$ & $\begin{array}{l}2.399 * * * \\
(0.200)\end{array}$ & $\begin{array}{l}2.582 * * * \\
(0.227)\end{array}$ & $\begin{array}{l}1.934 * * * \\
(0.194)\end{array}$ \\
\hline Observations & 208 & 454 & 458 & 470 & 200 \\
\hline First observation & 1995 & 1975 & 1975 & 1975 & 1995 \\
\hline R-squared & 0.910 & 0.855 & 0.716 & 0.803 & 0.883 \\
\hline
\end{tabular}

Robust standard errors in parentheses.

$* * * p<0.01, * * p<0.05, * p<0.1$ 
ANNEX 4

\section{CHANGING THE COUNTRY GROUPING}

TABLe A7 (a)

Changing the country grouping

15 year average potential GDP growth (in PPP)

\begin{tabular}{|c|c|c|c|c|c|}
\hline Variables & $\begin{array}{c}\text { EU27 } \\
\text { (baseline) }\end{array}$ & $\begin{array}{c}\text { EU27 } \\
\text { (excl. GR) }\end{array}$ & EU (15) & $\begin{array}{c}\text { EU (15) } \\
\text { (excl. GR) }\end{array}$ & CEECs (10) \\
\hline Catching-up & $\begin{array}{l}-0.589 * * * \\
(0.0386)\end{array}$ & $\begin{array}{l}-0.573 * * * \\
(0.0350)\end{array}$ & $\begin{array}{l}-0.407 * * * \\
(0.0422)\end{array}$ & $\begin{array}{l}-0.398 * * * \\
(0.0426)\end{array}$ & $\begin{array}{l}-0.634 * * * \\
(0.0712)\end{array}$ \\
\hline Institutions & $\begin{array}{l}0.0951 * * * \\
(0.0317)\end{array}$ & $\begin{array}{l}0.0833 * * * \\
(0.0288)\end{array}$ & $\begin{array}{l}0.0671 * * \\
(0.0271)\end{array}$ & $\begin{array}{l}0.0629^{* *} \\
(0.0262)\end{array}$ & $\begin{array}{c}0.0722 \\
(0.0777)\end{array}$ \\
\hline$($ Debt $>60)$ & $\begin{array}{l}-0.0394 * \\
(0.0197) \\
\end{array}$ & $\begin{array}{l}-0.0294 * \\
(0.0164) \\
\end{array}$ & $\begin{array}{l}-0.0519^{* *} \\
(0.0228)\end{array}$ & $\begin{array}{l}-0.0342 \\
(0.0194) \\
\end{array}$ & $\begin{array}{l}-0.120^{* *} \\
(0.0436)\end{array}$ \\
\hline $\begin{array}{l}(\text { Debt }>60) \mathrm{x} \\
\text { Institutions }\end{array}$ & $\begin{array}{l}0.131 * * * \\
(0.0283)\end{array}$ & $\begin{array}{l}0.120 * * * \\
(0.0231)\end{array}$ & $\begin{array}{l}0.142 * * * \\
(0.0359)\end{array}$ & $\begin{array}{l}0.117 * * * \\
(0.0335)\end{array}$ & $\begin{array}{c}0.0626 \\
(0.0504) \\
\end{array}$ \\
\hline Constant & $\begin{array}{l}2.127 * * * \\
(0.0988)\end{array}$ & $\begin{array}{l}2.085 * * * \\
(0.0897)\end{array}$ & $\begin{array}{l}1.605^{* * *} \\
(0.124)\end{array}$ & $\begin{array}{l}1.579 * * * \\
(0.126)\end{array}$ & $\begin{array}{l}2.210^{* * * *} \\
(0.192)\end{array}$ \\
\hline Observations & 208 & 200 & 120 & 112 & 80 \\
\hline R-squared & 0.911 & 0.914 & 0.659 & 0.675 & 0.862 \\
\hline
\end{tabular}

Robust standard errors in parentheses.

*** $p<0.01, * * p<0.05, * p<0.1$

TABLe A7 (b)

Changing the country grouping (2SLS)

15 year average potential GDP growth (in PPP)

\begin{tabular}{|c|c|c|c|c|}
\hline Variables & $\begin{array}{c}\text { EU27 } \\
\text { (baseline) }\end{array}$ & $\begin{array}{c}\text { EU27 } \\
\text { (excl. GR) }\end{array}$ & EU (15) & $\begin{array}{c}\text { EU (15) } \\
\text { (excl. GR) }\end{array}$ \\
\hline Catching-up & $\begin{array}{l}-0.611 * * * \\
(0.0413)\end{array}$ & $\begin{array}{l}-0.596 * * * \\
(0.0399)\end{array}$ & $\begin{array}{l}-0.415 * * * \\
(0.0513)\end{array}$ & $\begin{array}{l}-0.413 * * * \\
(0.0541)\end{array}$ \\
\hline Institutions & $\begin{array}{l}0.116^{* * *} \\
(0.0394)\end{array}$ & $\begin{array}{l}0.104 * * * \\
(0.0374)\end{array}$ & $\begin{array}{l}0.0787 * * \\
(0.0394)\end{array}$ & $\begin{array}{l}0.0787 * * \\
(0.0401)\end{array}$ \\
\hline$(\mathrm{Debt}>60)$ & $\begin{array}{l}-0.0357^{*} \\
(0.0186)\end{array}$ & $\begin{array}{l}-0.0284 \\
(0.0173)\end{array}$ & $\begin{array}{l}-0.0419^{*} \\
(0.0220)\end{array}$ & $\begin{array}{l}-0.0172 \\
(0.0218)\end{array}$ \\
\hline $\begin{array}{l}(\text { Debt }>60) \mathrm{x} \\
\text { Institutions }\end{array}$ & $\begin{array}{l}0.123 * * * \\
(0.0289)\end{array}$ & $\begin{array}{l}0.122 * * * \\
(0.0293)\end{array}$ & $\begin{array}{l}0.122 * * * \\
(0.0362)\end{array}$ & $\begin{array}{l}0.0868^{* *} \\
(0.0366)\end{array}$ \\
\hline Constant & $\begin{array}{l}2.181 * * * \\
(0.105)\end{array}$ & $\begin{array}{l}2.145^{* * *} \\
(0.100)\end{array}$ & $\begin{array}{l}1.621 * * * \\
(0.148)\end{array}$ & $\begin{array}{l}1.615^{* * *} \\
(0.156)\end{array}$ \\
\hline Observations & 208 & 200 & 120 & 112 \\
\hline R-squared & 0.910 & 0.913 & 0.657 & 0.672 \\
\hline
\end{tabular}

Robust standard errors in parentheses.

$* * * p<0.01, * * p<0.05, * p<0.1$ 
ANNEX 5

EXPANDING THE ORIGINAL MODEL WITH ADDITIONAL VARIABLE AND WITH

DIFFERENT PROXY OF INSTITUTIONAL QUALITY

\section{TABle A8 (1)}

Institutions refers to Economic Complexity

15 year average potential GDP growth (in PPP)

\begin{tabular}{|c|c|c|c|c|c|c|c|}
\hline \multirow[b]{2}{*}{ Catching-up } & \\
\hline & $\begin{array}{l}-0.522 * * * \\
(0.0179) \\
\end{array}$ & $\begin{array}{l}-0.539 * * * \\
(0.0172) \\
\end{array}$ & $\begin{array}{l}-0.484 * * * \\
(0.0281) \\
\end{array}$ & $\begin{array}{l}-0.484^{* * *} \\
(0.0228) \\
\end{array}$ & $\begin{array}{l}-0.507 * * * \\
(0.0310) \\
\end{array}$ & $\begin{array}{l}-0.468 * * * \\
(0.0345) \\
\end{array}$ & $\begin{array}{l}-0.488^{* * *} \\
(0.0304) \\
\end{array}$ \\
\hline Institutions & $\begin{array}{l}0.0676^{* *} \\
(0.0321) \\
\end{array}$ & $\begin{array}{l}0.0923^{* * *} \\
(0.0227) \\
\end{array}$ & $\begin{array}{c}0.0254 \\
(0.0373) \\
\end{array}$ & $\begin{array}{c}0.00484 \\
(0.0282) \\
\end{array}$ & $\begin{array}{c}0.0113 \\
(0.0308) \\
\end{array}$ & $\begin{array}{r}0.00737 \\
(0.0292) \\
\end{array}$ & $\begin{array}{c}0.0262 \\
(0.0323) \\
\end{array}$ \\
\hline$($ Debt $>60)$ & $\begin{array}{r}0.0230 \\
(0.0326) \\
\end{array}$ & $\begin{array}{c}0.0133 \\
(0.0283) \\
\end{array}$ & $\begin{array}{l}-0.00750 \\
(0.0364) \\
\end{array}$ & $\begin{array}{l}-0.0412 \\
(0.0241) \\
\end{array}$ & $\begin{array}{l}-0.0225 \\
(0.0275) \\
\end{array}$ & $\begin{array}{l}-0.0130 \\
(0.0196) \\
\end{array}$ & $\begin{array}{r}0.00696 \\
(0.0204) \\
\end{array}$ \\
\hline $\begin{array}{l}(\text { Debt }>60) x \\
\text { Institutions }\end{array}$ & $\begin{array}{r}0.0535 \\
(0.0389) \\
\end{array}$ & $\begin{array}{c}0.0136 \\
(0.0432) \\
\end{array}$ & $\begin{array}{l}0.103 * * * \\
(0.0355) \\
\end{array}$ & $\begin{array}{l}0.129 * * * \\
(0.0284) \\
\end{array}$ & $\begin{array}{c}0.107 * * \\
(0.0394) \\
\end{array}$ & $\begin{array}{l}0.0955^{* * * *} \\
(0.0246) \\
\end{array}$ & $\begin{array}{l}0.0610 * * \\
(0.0279)\end{array}$ \\
\hline $\begin{array}{l}\text { Trade } \\
\text { openness }\end{array}$ & & $\begin{array}{l}0.123^{* * *} \\
(0.0334) \\
\end{array}$ & & & & & $\begin{array}{l}0.0658 * * \\
(0.0284)\end{array}$ \\
\hline $\begin{array}{l}\text { Government } \\
\text { expenditure }\end{array}$ & & & $\begin{array}{l}-0.135 \\
(0.131) \\
\end{array}$ & & & & $\begin{array}{l}-0.128 \\
(0.113) \\
\end{array}$ \\
\hline Savings rate & & & & $\begin{array}{l}-0.00126 \\
(0.00179) \\
\end{array}$ & & & $\begin{array}{c}0.00234 \\
(0.00257) \\
\end{array}$ \\
\hline $\begin{array}{l}\text { Participation } \\
\text { rate }\end{array}$ & & & & & $\begin{array}{r}0.00294^{*} \\
(0.00147) \\
\end{array}$ & & $\begin{array}{l}0.00639 * * * \\
(0.00198) \\
\end{array}$ \\
\hline Education & & & & & & $\begin{array}{c}0.00126 \\
(0.000925) \\
\end{array}$ & $\begin{array}{c}0.00124 \\
(0.000847) \\
\end{array}$ \\
\hline Constant & $\begin{array}{l}1.941^{* * *} \\
(0.0448) \\
\end{array}$ & $\begin{array}{l}1.469^{* * *} \\
(0.130) \\
\end{array}$ & $\begin{array}{l}1.749 * * * \\
(0.125) \\
\end{array}$ & $\begin{array}{l}1.882 * * * \\
(0.0556) \\
\end{array}$ & $\begin{array}{c}1.715^{* * *} \\
(0.0906) \\
\end{array}$ & $\begin{array}{l}1.821^{* * *} \\
(0.0927) \\
\end{array}$ & $\begin{array}{l}0.995^{* * * *} \\
(0.194) \\
\end{array}$ \\
\hline Observations & 454 & 454 & 270 & 311 & 307 & 200 & 183 \\
\hline R-squared & 0.873 & 0.901 & 0.866 & 0.900 & 0.896 & 0.840 & 0.925 \\
\hline
\end{tabular}

Robust standard errors in parentheses.

$* * * p<0.01, * * p<0.05, * p<0.1$ 
Table A8 (2)

Institutions refers to Chinn-Ito Index

15 year average potential GDP growth (in PPP)

\begin{tabular}{|c|c|c|c|c|c|c|c|}
\hline Catching-up & $\begin{array}{l}-0.538^{* * *} \\
(0.0161)\end{array}$ & $\begin{array}{l}-0.546^{* * *} \\
(0.0175) \\
\end{array}$ & $\begin{array}{l}-0.503^{* * *} \\
(0.0245) \\
\end{array}$ & $\begin{array}{l}-0.515^{* * *} \\
(0.0248) \\
\end{array}$ & $\begin{array}{l}-0.532^{* * *} \\
(0.0220) \\
\end{array}$ & $\begin{array}{l}-0.488 * * * \\
(0.0262) \\
\end{array}$ & $\begin{array}{l}-0.530^{* * *} \\
(0.0444) \\
\end{array}$ \\
\hline Institutions & $\begin{array}{l}0.0371 * * * \\
(0.0102)\end{array}$ & $\begin{array}{l}0.0353^{* * * *} \\
(0.00996)\end{array}$ & $\begin{array}{c}0.0254^{* *} \\
(0.00915)\end{array}$ & $\begin{array}{l}0.0241^{* * *} \\
(0.00861)\end{array}$ & $\begin{array}{c}0.0154 \\
(0.00946)\end{array}$ & $\begin{array}{c}0.0241 * * \\
(0.00959)\end{array}$ & $\begin{array}{l}0.0276 * * * \\
(0.00956)\end{array}$ \\
\hline$($ Debt $>60)$ & $\begin{array}{l}0.0303 \\
(0.0312)\end{array}$ & $\begin{array}{c}0.0205 \\
(0.0254) \\
\end{array}$ & $\begin{array}{l}-0.00282 \\
(0.0345)\end{array}$ & $\begin{array}{l}-0.0181 \\
(0.0246)\end{array}$ & $\begin{array}{c}0.00283 \\
(0.0213)\end{array}$ & $\begin{array}{c}0.00279 \\
(0.0244)\end{array}$ & $\begin{array}{l}-0.000956 \\
(0.0197)\end{array}$ \\
\hline $\begin{array}{l}(\text { Debt }>60) \mathrm{x} \\
\text { Institutions }\end{array}$ & $\begin{array}{l}-0.00929 \\
(0.0191)\end{array}$ & $\begin{array}{l}-0.00528 \\
(0.0170)\end{array}$ & $\begin{array}{r}0.00941 \\
(0.0148)\end{array}$ & $\begin{array}{c}0.0216 \\
(0.0166)\end{array}$ & $\begin{array}{c}0.0293 * * \\
(0.0129)\end{array}$ & $\begin{array}{c}0.00408 \\
(0.0154)\end{array}$ & $\begin{array}{c}0.0147 \\
(0.0145)\end{array}$ \\
\hline $\begin{array}{l}\text { Trade } \\
\text { openness }\end{array}$ & & $\begin{array}{l}0.0680^{* *} \\
(0.0322) \\
\end{array}$ & & & & & $\begin{array}{c}0.0639^{* *} \\
(0.0286)\end{array}$ \\
\hline $\begin{array}{l}\text { Government } \\
\text { expenditure }\end{array}$ & & & $\begin{array}{l}-0.0435 \\
(0.0879) \\
\end{array}$ & & & & $\begin{array}{l}-0.0256 \\
(0.0901)\end{array}$ \\
\hline Savings rate & & & & $\begin{array}{r}0.000670 \\
(0.00168) \\
\end{array}$ & & & $\begin{array}{c}0.00402 \\
(0.00296) \\
\end{array}$ \\
\hline $\begin{array}{l}\text { Participation } \\
\text { rate }\end{array}$ & & & & & $\begin{array}{l}0.00313^{* *} \\
(0.00145)\end{array}$ & & $\begin{array}{c}0.00663 * * \\
(0.00259)\end{array}$ \\
\hline Education & & & & & & $\begin{array}{c}0.00161^{* *} \\
(0.000698)\end{array}$ & $\begin{array}{c}0.00175^{*} \\
(0.000903)\end{array}$ \\
\hline Constant & $\begin{array}{l}2.000 * * * \\
(0.0467)\end{array}$ & $\begin{array}{l}1.735^{* * *} \\
(0.140) \\
\end{array}$ & $\begin{array}{l}1.869^{* * *} \\
(0.114) \\
\end{array}$ & $\begin{array}{l}1.935^{* * *} \\
(0.0565)\end{array}$ & $\begin{array}{l}1.764 * * * \\
(0.0997)\end{array}$ & $\begin{array}{l}1.864 * * * \\
(0.0715)\end{array}$ & $\begin{array}{l}1.155^{* * *} \\
(0.229)\end{array}$ \\
\hline Observations & 458 & 458 & 280 & 307 & 316 & 207 & 187 \\
\hline R-squared & 0.865 & 0.875 & 0.842 & 0.885 & 0.889 & 0.826 & 0.920 \\
\hline
\end{tabular}

Robust standard errors in parentheses.

$* * * p<0.01, * * p<0.05, * p<0.1$ 
TABle A8 (3)

Institutions refers to Economic Freedom from the Fraser Institute

15 year average potential GDP growth (in PPP)

\begin{tabular}{|c|c|c|c|c|c|c|c|}
\hline Catching-up & $\begin{array}{l}-0.596 * * * \\
(0.0255)\end{array}$ & $\begin{array}{l}-0.589^{* * * *} \\
(0.0230)\end{array}$ & $\begin{array}{l}-0.576^{* * *} \\
(0.0273)\end{array}$ & $\begin{array}{l}-0.565^{* * *} \\
(0.0324)\end{array}$ & $\begin{array}{l}-0.573 * * * \\
(0.0241)\end{array}$ & $\begin{array}{l}-0.549 * * * \\
(0.0349)\end{array}$ & $\begin{array}{l}-0.560 * * * \\
(0.0623)\end{array}$ \\
\hline Institutions & $\begin{array}{l}0.0757 * * * \\
(0.0218)\end{array}$ & $\begin{array}{l}0.0681 * * * \\
(0.0176)\end{array}$ & $\begin{array}{l}0.0555^{* * *} \\
(0.0195)\end{array}$ & $\begin{array}{l}0.0468^{* * *} \\
(0.0162)\end{array}$ & $\begin{array}{c}0.0378^{*} \\
(0.0191)\end{array}$ & $\begin{array}{l}0.0581^{* *} \\
(0.0268)\end{array}$ & $\begin{array}{c}0.0497^{*} \\
(0.0244) \\
\end{array}$ \\
\hline$($ Debt $>60)$ & $\begin{array}{c}0.0226 \\
(0.0239)\end{array}$ & $\begin{array}{c}0.0172 \\
(0.0218)\end{array}$ & $\begin{array}{l}-0.0188 \\
(0.0180)\end{array}$ & $\begin{array}{l}-0.0189 \\
(0.0186)\end{array}$ & $\begin{array}{l}-0.00253 \\
(0.0169)\end{array}$ & $\begin{array}{l}-0.0307 \\
(0.0182)\end{array}$ & $\begin{array}{l}-0.00529 \\
(0.0219)\end{array}$ \\
\hline $\begin{array}{l}(\text { Debt }>60) \mathrm{x} \\
\text { Institutions }\end{array}$ & $\begin{array}{l}0.0522 * * \\
(0.0206)\end{array}$ & $\begin{array}{l}0.0465^{*} \\
(0.0241)\end{array}$ & $\begin{array}{l}0.104 * * * \\
(0.0178)\end{array}$ & $\begin{array}{l}0.0707 * * \\
(0.0271)\end{array}$ & $\begin{array}{l}0.0808^{* * *} \\
(0.0234)\end{array}$ & $\begin{array}{l}0.104 * * * \\
(0.0277)\end{array}$ & $\begin{array}{c}0.0475^{*} \\
(0.0273)\end{array}$ \\
\hline $\begin{array}{l}\text { Trade } \\
\text { openness }\end{array}$ & & $\begin{array}{c}0.0410 \\
(0.0317)\end{array}$ & & & & & $\begin{array}{c}0.0444 \\
(0.0330) \\
\end{array}$ \\
\hline $\begin{array}{l}\text { Government } \\
\text { expenditure }\end{array}$ & & & $\begin{array}{l}-0.0290 \\
(0.0777)\end{array}$ & & & & $\begin{array}{l}0.00126 \\
(0.102)\end{array}$ \\
\hline Savings rate & & & & $\begin{array}{c}0.00103 \\
(0.00169)\end{array}$ & & & $\begin{array}{c}0.00392 \\
(0.00281)\end{array}$ \\
\hline $\begin{array}{l}\text { Participation } \\
\text { rate }\end{array}$ & & & & & $\begin{array}{l}0.00306^{* *} \\
(0.00146)\end{array}$ & & $\begin{array}{c}0.00652^{* *} \\
(0.00265)\end{array}$ \\
\hline Education & & & & & & $\begin{array}{c}0.00128^{*} \\
(0.000692)\end{array}$ & $\begin{array}{c}0.00154 \\
(0.000968) \\
\end{array}$ \\
\hline Constant & $\begin{array}{l}2.139^{* * *} \\
(0.0664)\end{array}$ & $\begin{array}{l}1.951^{* * *} \\
(0.136)\end{array}$ & $\begin{array}{l}2.062^{* * * *} \\
(0.0898)\end{array}$ & $\begin{array}{l}2.057 * * * \\
(0.0722)\end{array}$ & $\begin{array}{l}1.868^{* * *} \\
(0.113)\end{array}$ & $\begin{array}{l}2.017 * * * \\
(0.0941)\end{array}$ & $\begin{array}{l}1.343^{* * *} \\
(0.285)\end{array}$ \\
\hline Observations & 470 & 470 & 286 & 319 & 323 & 207 & 187 \\
\hline R-squared & 0.882 & 0.886 & 0.881 & 0.903 & 0.904 & 0.867 & 0.916 \\
\hline
\end{tabular}

Robust standard errors in parentheses.

$* * * p<0.01$, ** $p<0.05$, * $p<0.1$ 
TABLe A8 (4)

Institutions refers to Economic Freedom from the Heritage Foundation

15 year average potential GDP growth (in PPP)

\begin{tabular}{|c|c|c|c|c|c|c|c|}
\hline Catching-up & $\begin{array}{l}-0.519^{* * *} \\
(0.0264)\end{array}$ & $\begin{array}{l}-0.513^{* * *} \\
(0.0276) \\
\end{array}$ & $\begin{array}{l}-0.537 * * * \\
(0.0306)\end{array}$ & $\begin{array}{l}-0.496 * * * \\
(0.0296)\end{array}$ & $\begin{array}{l}-0.527 * * * \\
(0.0224) \\
\end{array}$ & $\begin{array}{l}-0.489^{* * *} \\
(0.0250) \\
\end{array}$ & $\begin{array}{l}-0.520^{* * * *} \\
(0.0513)\end{array}$ \\
\hline Institutions & $\begin{array}{c}0.00445^{*} \\
(0.00238) \\
\end{array}$ & $\begin{array}{c}0.00401 * \\
(0.00226) \\
\end{array}$ & $\begin{array}{c}0.00542^{* *} \\
(0.00212) \\
\end{array}$ & $\begin{array}{c}0.00276 \\
(0.00212) \\
\end{array}$ & $\begin{array}{c}0.00409 \\
(0.00247) \\
\end{array}$ & $\begin{array}{c}0.00410 \\
(0.00275) \\
\end{array}$ & $\begin{array}{c}0.00344 \\
(0.00229)\end{array}$ \\
\hline$($ Debt $>60)$ & $\begin{array}{r}0.00215 \\
(0.0248) \\
\end{array}$ & $\begin{array}{r}0.00259 \\
(0.0234) \\
\end{array}$ & $\begin{array}{l}-0.00067 \\
(0.0260) \\
\end{array}$ & $\begin{array}{l}-0.0135 \\
(0.0281) \\
\end{array}$ & $\begin{array}{c}0.0220 \\
(0.0211) \\
\end{array}$ & $\begin{array}{r}0.00771 \\
(0.0230) \\
\end{array}$ & $\begin{array}{c}0.0219 \\
(0.0209)\end{array}$ \\
\hline $\begin{array}{l}\text { Debt }>60) \mathrm{x} \\
\text { Institutions }\end{array}$ & $\begin{array}{l}0.0108^{* * *} \\
(0.00277)\end{array}$ & $\begin{array}{l}0.0104^{* * *} \\
(0.00245)\end{array}$ & $\begin{array}{l}0.0102 * * * \\
(0.00320)\end{array}$ & $\begin{array}{l}0.0102^{* * *} \\
(0.00290)\end{array}$ & $\begin{array}{l}0.01000^{* * *} \\
(0.00245) \\
\end{array}$ & $\begin{array}{l}0.0106^{* * *} \\
(0.00376) \\
\end{array}$ & $\begin{array}{c}0.00303 \\
(0.00315) \\
\end{array}$ \\
\hline $\begin{array}{l}\text { Trade } \\
\text { openness }\end{array}$ & & $\begin{array}{c}0.0313 \\
(0.0370) \\
\end{array}$ & & & & & $\begin{array}{c}0.0493 \\
(0.0376) \\
\end{array}$ \\
\hline $\begin{array}{l}\text { Government } \\
\text { expenditure }\end{array}$ & & & $\begin{array}{r}0.0915 \\
(0.131) \\
\end{array}$ & & & & $\begin{array}{r}0.0353 \\
(0.137) \\
\end{array}$ \\
\hline Savings rate & & & & $\begin{array}{l}-0.00132 \\
(0.00215) \\
\end{array}$ & & & $\begin{array}{c}0.00322 \\
(0.00295)\end{array}$ \\
\hline $\begin{array}{l}\text { Participation } \\
\text { rate }\end{array}$ & & & & & $\begin{array}{c}0.00469^{* *} \\
(0.00201)\end{array}$ & & $\begin{array}{l}0.00719^{* * *} \\
(0.00249)\end{array}$ \\
\hline Education & & & & & & $\begin{array}{c}0.00171 * * * \\
(0.000603) \\
\end{array}$ & $\begin{array}{c}0.00145 \\
(0.000910)\end{array}$ \\
\hline Constant & $\begin{array}{c}1.941^{* * *} \\
(0.0694)\end{array}$ & $\begin{array}{l}1.786^{* * *} \\
(0.185)\end{array}$ & $\begin{array}{l}2.062^{* * * *} \\
(0.167) \\
\end{array}$ & $\begin{array}{c}1.900 * * * \\
(0.0706) \\
\end{array}$ & $\begin{array}{l}1.625^{* * * *} \\
(0.160) \\
\end{array}$ & $\begin{array}{l}1.860 * * * \\
(0.0698) \\
\end{array}$ & $\begin{array}{l}1.205^{* * *} \\
(0.286)\end{array}$ \\
\hline Observations & 200 & 200 & 200 & 187 & 200 & 170 & 163 \\
\hline R-squared & 0.883 & 0.886 & 0.885 & 0.896 & 0.893 & 0.875 & 0.909 \\
\hline
\end{tabular}

Robust standard errors in parentheses.

$* * * p<0.01, * * p<0.05, * p<0.1$ 
ANNEX 6

T-STATISTICS OF MODEL (5)

TABLe A9 (1)

t-statistic of the catching-up term in equation (5)

Base 1996199719981999200020012002200320042005200620072008200920102011201220132014 Span

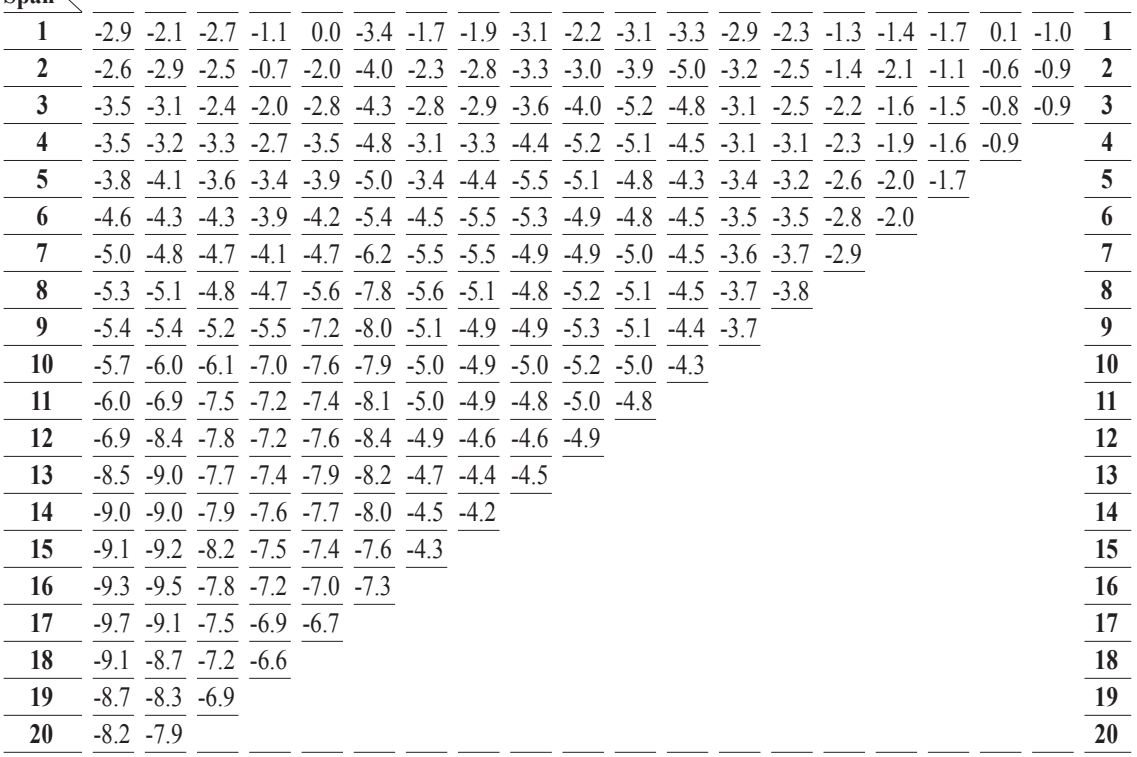

$\overline{1996} \overline{1997} \overline{1998} \overline{1999} \overline{2000} \overline{2001} \overline{2002} \overline{2003} \overline{2004} \overline{2005} \overline{2006} \overline{2007} \overline{2008} \overline{2009} \overline{2010} \overline{2011} \overline{2012} \overline{2013} \overline{2014}$

TABle A9 (2)

t-statistic of the institutions term in equation (5)

Base 1996199719981999200020012002200320042005200620072008200920102011201220132014 Span

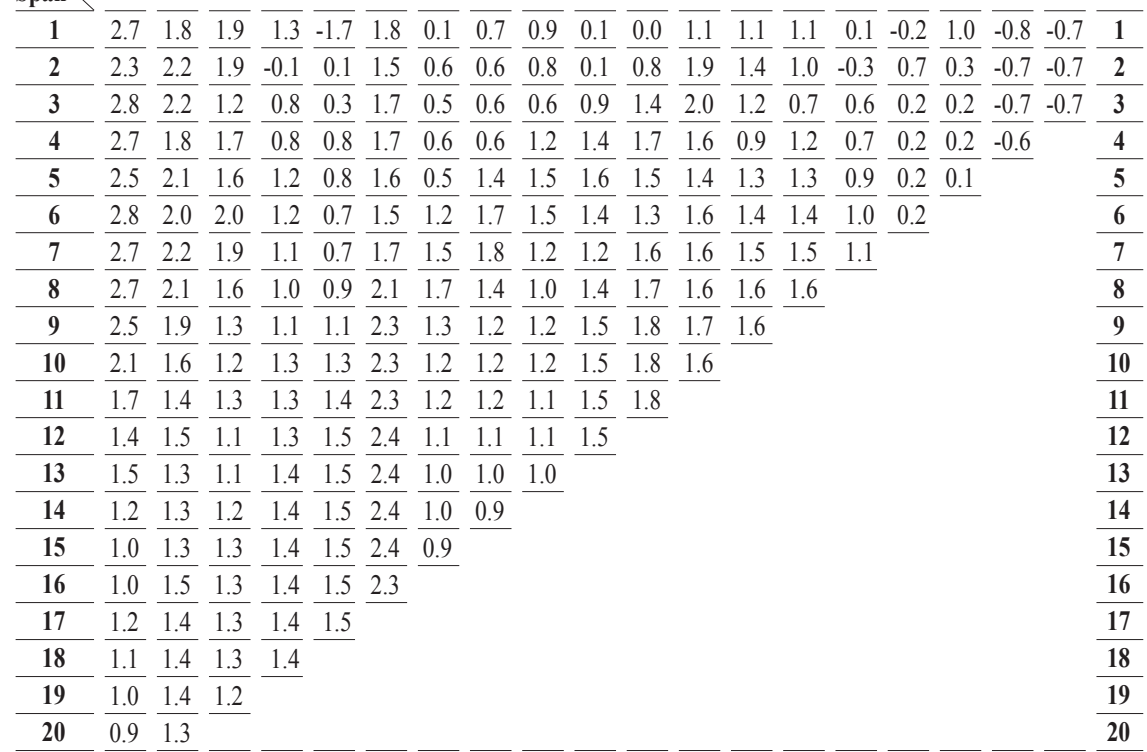

$\overline{1996} \overline{1997} \overline{1998} \overline{1999} \overline{2000} \overline{2001} \overline{2002} \overline{2003} \overline{2004} \overline{2005} \overline{2006} \overline{2007} \overline{2008} \overline{2009} \overline{2010} \overline{2011} \overline{2012} \overline{2013} \overline{2014}$ 
TABle A9 (3)

t-statistic of the debt dummy term in equation (5)

Base 1996199719981999200020012002200320042005200620072008200920102011201220132014 Span

\begin{tabular}{|c|c|c|c|c|c|c|c|c|c|c|c|c|c|c|c|c|c|c|c|c|}
\hline 1 & $\overline{1.2}$ & 1.6 & $\overline{-1.5}$ & $\overline{-0.2}$ & $\overline{-2.1}$ & $\overline{-0.2}$ & $\overline{-0.8}$ & $\overline{-1.1}$ & $\overline{0.5}$ & $\overline{-1.7}$ & $\overline{-3.2}$ & $\overline{-0.5}$ & $\overline{1.4}$ & 0.3 & $\overline{-1.5}$ & $\overline{-1.7}$ & $\overline{-0.5}$ & $\overline{-1.6}$ & $\overline{-2.1}$ & 1 \\
\hline 2 & 1.2 & 1.0 & $\overline{-0.2}$ & -1.4 & $\overline{-1.1}$ & 0.0 & $\overline{-1.1}$ & $\overline{-1.1}$ & $\overline{-0.1}$ & $\overline{-2.5}$ & $\overline{-1.7}$ & 0.4 & 0.9 & $\overline{-0.5}$ & $\overline{-2.2}$ & $\overline{-1.2}$ & $\overline{-1.2}$ & $\overline{-2.0}$ & $\overline{-2.2}$ & 2 \\
\hline 3 & 1.3 & 1.4 & 0.0 & -1.0 & $\overline{-0.8}$ & $\overline{-0.5}$ & $\overline{-1.2}$ & $\overline{-0.9}$ & $\overline{-0.9}$ & $\overline{-1.2}$ & $\overline{-0.8}$ & 0.4 & 0.0 & -1.0 & $\overline{-1.1}$ & $\overline{-1.6}$ & $\overline{-1.4}$ & $\overline{-2.2}$ & $\overline{-2.2}$ & 3 \\
\hline 4 & 1.4 & 1.6 & 0.3 & $\overline{-0.9}$ & $\overline{-1.0}$ & $\overline{-0.9}$ & $\overline{-1.0}$ & -1.1 & $\overline{-0.1}$ & $\overline{-0.7}$ & -0.5 & -0.4 & $\overline{-0.6}$ & -0.5 & $\overline{-0.9}$ & $\overline{-1.6}$ & -1.5 & $\overline{-2.2}$ & & 4 \\
\hline 5 & 1.9 & 1.8 & $\overline{-0.1}$ & $\overline{-1.1}$ & $\overline{-1.3}$ & $\overline{-0.8}$ & $\overline{-1.2}$ & $\overline{0.0}$ & 0.0 & $\overline{-0.5}$ & $\overline{-0.9}$ & -1.0 & $\overline{-0.5}$ & -0.3 & $\overline{-0.6}$ & $\overline{-1.7}$ & $\overline{-1.6}$ & & & 5 \\
\hline 6 & 2.2 & 1.5 & $\overline{-0.5}$ & -1.3 & $\overline{-1.2}$ & $\overline{-1.1}$ & $\overline{-0.2}$ & 0.2 & 0.0 & $\overline{-1.2}$ & $\overline{-1.3}$ & -0.9 & $\overline{-0.4}$ & -0.2 & $\overline{-0.5}$ & $\overline{-1.7}$ & & & & 6 \\
\hline 7 & 2.0 & 1.1 & $\overline{-0.9}$ & -1.1 & -1.5 & $\overline{-0.9}$ & $\overline{-0.1}$ & 0.3 & $\overline{-0.7}$ & $\overline{-1.7}$ & $\overline{-1.2}$ & -0.8 & $\overline{-0.5}$ & -0.1 & $\overline{-0.4}$ & & & & & 7 \\
\hline 8 & 1.6 & 0.7 & $\overline{-0.7}$ & -1.1 & $\overline{-1.2}$ & -0.7 & 0.0 & $\overline{-0.4}$ & -1.2 & $\overline{-1.7}$ & $\overline{-1.1}$ & -0.9 & $\overline{-0.6}$ & -0.1 & & & & & & 8 \\
\hline 9 & 1.1 & 0.8 & -0.7 & -1.0 & -1.2 & -0.5 & -0.6 & -0.7 & -1.2 & -1.7 & -1.1 & -1.0 & $\overline{-0.6}$ & & & & & & & 9 \\
\hline 10 & 1.0 & 0.8 & $\overline{-0.4}$ & -1.1 & $\overline{-1.2}$ & $\overline{-0.8}$ & $\overline{-1.0}$ & $\overline{-1.0}$ & $\overline{-1.4}$ & $\overline{-1.8}$ & $\overline{-1.1}$ & -1.0 & & & & & & & & 10 \\
\hline 11 & $\overline{0.6}$ & 0.6 & $\overline{-0.5}$ & $-\overline{-1.2}$ & $\overline{-1.2}$ & $\overline{-0.9}$ & $\overline{-1.2}$ & $-\overline{-1.2}$ & $\overline{-1.6}$ & $\overline{-1.9}$ & $\overline{-1.1}$ & & & & & & & & & 11 \\
\hline 12 & 0.5 & 0.6 & $\overline{-0.8}$ & -1.2 & -1.3 & -1.3 & -1.5 & $\overline{-1.4}$ & -1.8 & $\overline{-1.9}$ & & & & & & & & & & 12 \\
\hline 13 & 0.5 & 0.5 & $\overline{-0.8}$ & $\overline{-1.3}$ & $\overline{-1.6}$ & -1.2 & -1.7 & $-\overline{-1.5}$ & $\overline{-1.9}$ & & & & & & & & & & & 13 \\
\hline 14 & 0.1 & 0.4 & -1.0 & -1.6 & -1.6 & -1.2 & -1.8 & -1.7 & & & & & & & & & & & & 14 \\
\hline 15 & $\overline{-0.1}$ & 0.2 & $\overline{-1.3}$ & $-\overline{-1.5}$ & $\overline{-1.6}$ & -1.2 & $\overline{-1.9}$ & & & & & & & & & & & & & 15 \\
\hline 16 & $\overline{-0.4}$ & -0.1 & $\overline{-1.2}$ & $\overline{-1.5}$ & $\overline{-1.5}$ & $\overline{-1.2}$ & & & & & & & & & & & & & & 16 \\
\hline 17 & $\overline{-0.5}$ & -0.1 & $\overline{-1.3}$ & $\overline{-1.4}$ & -1.5 & & & & & & & & & & & & & & & 17 \\
\hline 18 & $\overline{-0.7}$ & -0.1 & $\overline{-1.3}$ & $\overline{-1.4}$ & & & & & & & & & & & & & & & & 18 \\
\hline 19 & $\overline{-0.8}$ & -0.2 & $\overline{-1.4}$ & & & & & & & & & & & & & & & & & 19 \\
\hline 20 & $\overline{-0.9}$ & -0.2 & & & & & & & & & & & & & & & & & & 20 \\
\hline
\end{tabular}

$\overline{1996} \overline{1997} \overline{1998} \overline{1999} \overline{2000} \overline{2001} \overline{2002} \overline{2003} \overline{2004} \overline{2005} \overline{2006} \overline{2007} \overline{2008} \overline{2009} \overline{2010} \overline{2011} \overline{2012} \overline{2013} \overline{2014}$

\section{Table A9 (4)}

$t$-statistic of the interaction term in equation (5)

Base 1996199719981999200020012002200320042005200620072008200920102011201220132014 Span

\begin{tabular}{|c|c|c|c|c|c|c|c|c|c|c|c|c|c|c|c|c|c|c|c|c|}
\hline 1 & $\overline{-1.3}$ & $\overline{-1.4}$ & 0.4 & $\overline{-1.2}$ & $\overline{-0.7}$ & 0.4 & $\overline{0.4}$ & 0.0 & 0.5 & 0.3 & 0.7 & $\overline{-0.4}$ & 0.2 & $\overline{1.0}$ & $\overline{1.9}$ & $\overline{1.9}$ & $\overline{0.8}$ & 2.6 & 3.0 & 1 \\
\hline 2 & $\overline{-1.0}$ & $\overline{-0.7}$ & 0.1 & -1.0 & 0.0 & 0.4 & $\overline{0.1}$ & 0.7 & $\overline{0.2}$ & 0.6 & 0.0 & $\overline{-0.3}$ & $\overline{1.1}$ & 1.5 & 2.7 & $\overline{1.4}$ & 2.1 & 3.3 & 3.0 & 2 \\
\hline 3 & $\overline{-1.0}$ & $\overline{-0.3}$ & $\overline{-0.4}$ & $\overline{-0.6}$ & 0.1 & 0.1 & $\overline{0.4}$ & 0.4 & $\overline{0.3}$ & 0.0 & 0.0 & 0.5 & $\overline{1.5}$ & 2.0 & 2.0 & 2.4 & 2.6 & 3.4 & 3.1 & 3 \\
\hline 4 & $\overline{-0.7}$ & $\overline{-0.4}$ & -0.2 & -0.2 & $\overline{-0.1}$ & 0.0 & 0.3 & 0.4 & $\overline{-0.3}$ & $\overline{0.0}$ & $\overline{0.6}$ & 1.1 & $\overline{1.9}$ & 1.7 & $\overline{2.3}$ & $\overline{2.7}$ & $\overline{2.8}$ & $\overline{3.4}$ & & 4 \\
\hline 5 & $\overline{-1.1}$ & 0.0 & $\overline{-0.5}$ & $\overline{-0.2}$ & $\overline{-0.1}$ & 0.0 & 0.3 & $\overline{-0.3}$ & $\overline{-0.1}$ & 0.5 & $\overline{1.0}$ & 1.5 & $\overline{1.6}$ & 2.0 & 2.4 & 2.9 & 2.9 & & & 5 \\
\hline 6 & $\overline{-1.0}$ & 0.0 & $\overline{-0.4}$ & -0.2 & 0.0 & $\overline{-0.1}$ & $\overline{-0.1}$ & $\overline{-0.2}$ & $\overline{0.4}$ & $\overline{1.1}$ & $\overline{1.4}$ & $\overline{1.3}$ & $\overline{1.9}$ & 2.1 & 2.4 & 3.0 & & & & 6 \\
\hline 7 & -0.8 & 0.1 & -0.5 & 0.0 & -0.1 & 0.1 & 0.0 & 0.3 & 1.1 & 1.5 & 1.2 & 1.7 & 1.8 & 2.1 & 2.4 & & & & & 7 \\
\hline 8 & $\overline{-0.5}$ & $\overline{0.1}$ & 0.0 & 0.3 & 0.2 & 0.4 & $\overline{0.4}$ & 0.9 & $\overline{1.4}$ & $\overline{1.4}$ & $\overline{1.5}$ & $\overline{1.6}$ & $\overline{1.7}$ & $\overline{2.2}$ & & & & & & 8 \\
\hline 9 & $\overline{-0.3}$ & 0.5 & 0.5 & 0.6 & 0.5 & 1.1 & $\overline{0.9}$ & 1.2 & 1.4 & $\overline{1.8}$ & $\overline{1.5}$ & $\overline{1.6}$ & $\overline{1.7}$ & & & & & & & 9 \\
\hline 10 & 0.2 & 1.0 & 1.1 & 0.8 & 1.4 & 1.4 & 1.2 & 1.4 & 1.9 & 1.8 & 1.4 & 1.6 & & & & & & & & 10 \\
\hline 11 & 0.9 & 1.5 & 1.3 & 1.5 & 1.6 & 1.6 & 1.3 & 1.8 & 2.0 & 1.8 & 1.4 & & & & & & & & & 11 \\
\hline 12 & 1.4 & 1.8 & 2.1 & 1.9 & 1.8 & 1.9 & 1.7 & 1.9 & 2.0 & 1.8 & & & & & & & & & & 12 \\
\hline 13 & 1.6 & 2.8 & 2.4 & 2.2 & 2.2 & 2.0 & 1.8 & 2.0 & 2.0 & & & & & & & & & & & 13 \\
\hline 14 & 2.5 & 3.1 & 2.6 & 2.6 & 2.2 & 1.9 & 1.8 & 2.0 & & & & & & & & & & & & 14 \\
\hline 15 & 3.0 & 3.4 & 2.9 & 2.7 & 2.2 & 1.8 & 1.8 & & & & & & & & & & & & & 15 \\
\hline 16 & 3.4 & 3.7 & 2.7 & 2.5 & 2.1 & 1.8 & & & & & & & & & & & & & & 16 \\
\hline 17 & 3.4 & 3.5 & 2.6 & 2.5 & 2.0 & & & & & & & & & & & & & & & 17 \\
\hline 18 & 3.4 & 3.4 & 2.4 & 2.4 & & & & & & & & & & & & & & & & 18 \\
\hline 19 & 3.4 & 3.3 & 2.3 & & & & & & & & & & & & & & & & & 19 \\
\hline 20 & 3.4 & 3.2 & & & & & & & & & & & & & & & & & & 20 \\
\hline
\end{tabular}

$\overline{1996} \overline{1997} \overline{1998} \overline{1999} \overline{2000} \overline{2001} \overline{2002} \overline{2003} \overline{2004} \overline{2005} \overline{2006} \overline{2007} \overline{2008} \overline{2009} \overline{2010} \overline{2011} \overline{2012} \overline{2013} \overline{2014}$ 
ANNEX 7

ADDITIONAL ROBUSTNESS CHECKS ON THE INSTRUMENTS USED

Changing legal origin for Croatia and Slovenia

Below we report a change in the instrumental variable method, by replacing the legal origins of Croatia and Slovenia with the German ones, as there are doubts about the classification of La Porta et al. (1999). The table shows that changing the legal origin of these two countries does not change the results of the baseline model.

TABLe A10

Modified legal origin

15-year average per capita potential growth

\begin{tabular}{|c|c|c|c|}
\hline Explanatory variables & OLS & 2SLS (LO) & 2SLS (LO mod) \\
\hline Log GDP (PPP) & $\begin{array}{l}-0.589 * * * \\
(0.0386)\end{array}$ & $\begin{array}{l}-0.611 * * * \\
(0.0413)\end{array}$ & $\begin{array}{l}-0.579 * * * \\
(0.0424)\end{array}$ \\
\hline Institutional delivery & $\begin{array}{l}0.0951^{* * * *} \\
(0.0317)\end{array}$ & $\begin{array}{l}0.116^{* * *} \\
(0.0394)\end{array}$ & $\begin{array}{l}0.0839 * * \\
(0.0408)\end{array}$ \\
\hline$($ Debt $>60)$ & $\begin{array}{l}-0.0394 * \\
(0.0197)\end{array}$ & $\begin{array}{l}-0.0357 * \\
(0.0186)\end{array}$ & $\begin{array}{l}-0.0420 * * \\
(0.0195)\end{array}$ \\
\hline $\begin{array}{l}(\text { Debt }>60) \mathrm{x} \\
\text { Institutional delivery }\end{array}$ & $\begin{array}{l}0.131 * * * \\
(0.0283)\end{array}$ & $\begin{array}{l}0.123 * * * \\
(0.0289)\end{array}$ & $\begin{array}{l}0.139 * * * \\
(0.0298)\end{array}$ \\
\hline Constant & $\begin{array}{l}2.127 * * * \\
(0.0988)\end{array}$ & $\begin{array}{l}2.181 * * * \\
(0.105)\end{array}$ & $\begin{array}{l}2.100 * * * \\
(0.107)\end{array}$ \\
\hline Observations & 208 & 208 & 208 \\
\hline R-squared & 0.911 & 0.910 & 0.911 \\
\hline
\end{tabular}

Robust standard errors in parentheses.

$* * * p<0.01$, ** $p<0.05, * p<0.1$

\section{Using human diversity (Ashraf and Galor, 2013)}

Below we report the change in the instrumental variable method, using genetic diversity as instrument. Compared to the original OLS and 2SLS legal origin regression the regression with genetic diversity has the same signs for the coefficients however less significant. The interaction term however is still significant at the $5 \%$ level.

\section{TABle A11}

Human diversity instrumenting institutions

\begin{tabular}{|c|c|c|c|}
\hline & \multicolumn{3}{|c|}{ 15-year average per capita potential growth } \\
\hline Explanatory variables & OLS & 2SLS (LO) & 2SLS (gen. div.) \\
\hline Log GDP (PPP) & $\begin{array}{l}-0.589 * * * \\
(0.0386)\end{array}$ & $\begin{array}{l}-0.611 * * * \\
(0.0413)\end{array}$ & $\begin{array}{l}-0.674 * * * \\
(0.121)\end{array}$ \\
\hline Institutional delivery & $\begin{array}{l}0.0951^{* * *} \\
(0.0317)\end{array}$ & $\begin{array}{l}0.116^{* * *} \\
(0.0394)\end{array}$ & $\begin{array}{c}0.163 \\
(0.124)\end{array}$ \\
\hline$($ Debt $>60)$ & $\begin{array}{l}-0.0394 * \\
(0.0197)\end{array}$ & $\begin{array}{l}-0.0357^{*} \\
(0.0186)\end{array}$ & $\begin{array}{l}-0.0357 \\
(0.0276)\end{array}$ \\
\hline $\begin{array}{l}(\text { Debt }>60) x \\
\text { Institutional delivery }\end{array}$ & $\begin{array}{l}0.131 * * * \\
(0.0283)\end{array}$ & $\begin{array}{l}0.123^{* * *} \\
(0.0289)\end{array}$ & $\begin{array}{r}0.161 * * \\
(0.0635) \\
\end{array}$ \\
\hline Constant & $\begin{array}{l}2.127 * * * \\
(0.0988)\end{array}$ & $\begin{array}{l}2.181 * * * \\
(0.105)\end{array}$ & $\begin{array}{l}2.341 * * * \\
(0.316)\end{array}$ \\
\hline Observations & 208 & 208 & 208 \\
\hline R-squared & 0.911 & 0.910 & 0.899 \\
\hline
\end{tabular}

Robust standard errors in parentheses. 
Using the institutional quality dataset by Kunčić (2014)

Complementary to the results presented in table 7 , where we experiment with different proxies of institutional quality as opposed to the baseline specification using the World Bank indicators, below we show regression results with institutional quality estimated by Kunčić (2014). Scores are demeaned in the first year and we are taking the average across the three dimensions legal, political and economic institutional quality, recorded in the dataset. Even though the magnitude of the coefficients differs due to different scales, the overall message remains broadly unchanged. For the OLS estimate significance levels are unchanged except for a slight drop for the debt dummy. In our 2SLS model specification institutions and the interaction term are significant at the 5 percent level. The marginal drop in explanatory power can be traced back to the longer time horizon of available data, starting in 1990, while the instrument is time constant.

TABle A12

Institutional quality as estimated by Kunčić

15-year average per capita potential growth

\begin{tabular}{|c|c|c|c|c|}
\hline $\begin{array}{l}\text { Explanatory } \\
\text { variables }\end{array}$ & OLS & 2SLS & OLS Kunčić & 2SLS Kunčić \\
\hline Log GDP (PPP) & $\begin{array}{l}-0.589 * * * \\
(0.0386)\end{array}$ & $\begin{array}{l}-0.611 * * * \\
(0.0413)\end{array}$ & $\begin{array}{l}-0.559 * * * \\
(0.0354)\end{array}$ & $\begin{array}{l}-0.693 * * * \\
(0.0930)\end{array}$ \\
\hline Institutions & $\begin{array}{l}0.0951^{* * *} \\
(0.0317)\end{array}$ & $\begin{array}{l}0.116^{* * * *} \\
(0.0394)\end{array}$ & $\begin{array}{l}0.457 * * * \\
(0.163)\end{array}$ & $\begin{array}{l}1.120^{* *} \\
(0.481)\end{array}$ \\
\hline$($ Debt $>60)$ & $\begin{array}{l}-0.0394 * \\
(0.0197)\end{array}$ & $\begin{array}{l}-0.0357^{*} \\
(0.0186)\end{array}$ & $\begin{array}{l}-0.0145 \\
(0.0245)\end{array}$ & $\begin{array}{l}-0.0155 \\
(0.0267)\end{array}$ \\
\hline $\begin{array}{l}(\text { Debt }>60) \mathrm{x} \\
\text { Institutional delivery }\end{array}$ & $\begin{array}{l}0.131^{* * *} \\
(0.0283)\end{array}$ & $\begin{array}{l}0.123^{* * * *} \\
(0.0289)\end{array}$ & $\begin{array}{l}0.616^{* * *} \\
(0.184)\end{array}$ & $\begin{array}{l}1.037 * * \\
(0.428)\end{array}$ \\
\hline Constant & $\begin{array}{l}2.127 * * * \\
(0.0988)\end{array}$ & $\begin{array}{l}2.181 * * * \\
(0.105)\end{array}$ & $\begin{array}{l}2.045^{* * *} \\
(0.0955)\end{array}$ & $\begin{array}{l}2.381 * * * \\
(0.236)\end{array}$ \\
\hline Observations & 208 & 208 & 277 & 277 \\
\hline R-squared & 0.911 & 0.910 & 0.849 & 0.798 \\
\hline
\end{tabular}

Robust standard errors in parentheses.

*** $p<0.01, * * p<0.05, * p<0.1$ 


\section{REFERENCES}

1. Acemoglu, D., Johnson, S. and Robinson, J., 2001. The Colonial Origins of Comparative Development: An Empirical Investigation. American Economic Review, (91), pp. 1369-1401. doi: 10.1257/aer.91.5.1369

2. Acemoglu, D., Johnson, S. and Robinson, J., 2002. Reversal of Fortune: Geography and Institutions in the Making of the Modern World Income Distribution. Quarterly Journal of Economics, pp. 1231-1294. doi: 10.1162/ 003355302320935025

3. Acemoglu, D., Johnson, S. and Robinson, J., 2004. Institutions as the fundamental cause of long-term growth. NBER, working paper, No. 10481.

4. Acemoglu, D., Johnson, S. and Robinson, J., 2005. The rise of Europe: Atlantic Trade, Institutional Change and Economic Growth. American Economic Review, 95(2), pp. 546-579. doi: 10.1257/0002828054201305

5. Ashraf, Q. and Galor, O., 2013. The 'Out of Africa' Hypothesis, Human Genetic Diversity, and Comparative Economic Development. American Economic Review, American Economic Association, 103(1), pp. 1-46.

6. Barnes, S. [et al.], 2013. The GDP Impact of Reform: a simple simulation framework. OECD Economics Department working papers, No. 834. doi: $10.1787 / 5 \mathrm{kgk} 9$ qjinhkmt-en

7. Barro, R. J., 1991. Economic Growth in a Cross Section of Countries. The Quarterly Journal of Economics, 106(2), pp. 407-443. doi: 10.2307/2937943

8. Barro, R. J., 1998. Determinants of Economic Growth: A Cross-Country Empirical Study. Cambridge: MIT Press.

9. Barro, R. J. and Sala-i-Martin, X., 1995. Economic growth. New York: McGraw-Hill.

10. Bassanini, A., Scarpetta, S. and Hemmings, P., 2001. Economic Growth: The Role of Policies and Institutions: Panel Data. Evidence from OECD Countries. OECD Economics Department Working Papers, No. 283.

11. Baum, A., Checherita-Westphal, C. and Rother, P., 2013. Debt and growth: New evidence for the euro area. Journal of International Money and Finance, 32(C), pp. 809-821. doi: 10.1016/j.jimonfin.2012.07.004

12. Berkowitz D., Pistor K. and Richard, J. F., 2003. Economic Developments, Legality, and the Transplant Effect. European Economic Review, 47(1), pp. 165-195. doi: 10.1016/S0014-2921(01)00196-9

13. Blanchard, O. and Wolfers, J., 2000. The role of shocks and institutions in the rise of European unemployment: the aggregate evidence. The Economic Journal, 110 (March). 10.1111/1468-0297.00518

14. Block, W. E., 1991. Economic Freedom: Toward a Theory of Measurement. Vancouver: The Fraser Institute.

15. Borsi, M. T. and Metiu, N., 2013. The evolution of economic convergence in the European Union. Discussion Paper Deutsche Bundesbank, No. 28/2013.

16. Campos, N. F., Coricelli, F. C. and Moretti, L., 2014. Economic growth and European integration: Estimating the Benefits from Membership in the European Union using the syntetic counterfactual method. IZA Discussion Paper, No. 8162 . 
17. Cecchetti, S. G., Mohanty, M. and Zampolli, F., 2011. The real effects of debt. BIS working papers No. 352.

18. Chalk, N. A. and Tanzi, V., 2002. "Impact of large public debt on growth in the EU: a discussion of potential channels" in: M. Buti [et al.]. The behaviour of fiscal authorities: stabilization, growth and institutions, pp. 186-211.

19. Chinn, M. D. and Ito, H., 2006. What Matters for Financial Development? Capital Controls, Institutions, and Interactions. Journal of Development Economics, 81(1), pp. 163-192. doi: 10.1016/j.jdeveco.2005.05.010

20. de Bandt, O. and Vigna, O., 2008. The macroeconomic impact of structural reforms. Quarterly selection of articles - Bulletin de la Banque de France, (11), pp. 5-32.

21. Easterly, W. and Rebelo, S., 1993. Fiscal Policy and Economic Growth: An Empirical Investigation. Journal of Monetary Economics, 32(3), pp. 417-458. doi: 10.1016/0304-3932(93)90025-B

22. ECB, 2015. Real convergence in the euro area: evidence, theory and policy implications. ECB Economic Bulletin, (5), pp. 30-45.

23. Eicher, T. and Leutkert, A., 2009. Institutions and Economic Performance: Endogeneity and Parameter Heterogenity. Journal of Money, Credit and Banking, 41(1), pp. 197-219. doi: 10.1111/j.1538-4616.2008.00193.x

24. European Commission, 2008. EMU@10: successes and challenges after 10 years of Economic and Monetary Union. European Economy, (2).

25. Fernández, C. and Garcia-Perea, P., 2015. The Impact of the Euro on Euro Area GDP Per Capita. Banco de Espana Working Paper, No. 1530.

26. Fernández-Villaverde, J., Garicano, L. and Santos, T., 2013. Political Credit Cycles: The Case of the Eurozone. Journal of Economic Perspectives, 27(3), pp. 145-166. doi: 10.1257/jep.27.3.145

27. Hall, R. and Jones C., 1999. Why do some countries produce so much more output per workers than others? Quarterly Journal of Economics, 114, pp. 83116. doi: 10.1162/003355399555954

28. Helliwell, J. F. [et al.], 2014. Good Governance and National Well-being. OECD Working Papers on Public Governance, (25). doi: 10.1787/5jxv9f$651 \mathrm{hvj}$-en

29. Hidalgo, C. A. and Ricardo, H., 2009. The Building Blocks of Economic Complexity. PNAS, 106 (26), pp. 10570-10575. doi: 10.1073/pnas.0900943106

30. Kaufmann, D., Kraay, A. and Mastruzzi, M., 2010. The Worldwide Governance Indicators: Methodology and Analytical Issues. World Bank Policy Research Working Paper, No. 5430.

31. Kunčić, A., 2014. Institutional quality dataset. Journal of Institutional Economics. Cambridge University Press, 10(01), pp. 135-161. doi: 10.1017/ S1744137413000192

32. La Porta, R. [et al.], 1999. The Quality of Goverment. Journal of Law, Economics, and Organization, 15(1), pp. 222-279. doi: 10.1093/jleo/15.1.222

33. Miller, T. and Kim, A. B., 2016. 2016 Index of Economic Freedom: Promoting Economic Opportunity and Prosperity. Washington: The Heritage Foundation $\&$ The Wall Street Journal. 
34. Ollivaud, P. and Turner, D., 2014. The Effect of the Global Financial Crisis on OECD Potential Output. OECD Economics Department working paper. doi: $10.1787 / 5 \mathrm{jxwt18h} 75 \mathrm{bw}-\mathrm{en}$

35. Rapacki, R. and Próchniak, M., 2009. The EU Enlargement and economic growth in the CEE: new member countries. European Commission, Economic Papers, No. 367.

36. Varga, J. and Veld, J., 2014. The potential growth impact of structural reforms in the EU. A benchmarking exercise. DG ECFIN European Economy - Economic Papers(541).

37. Wyplosz, C., 2007. Debt Sustainability Assessment: The IMF Approach and Alternatives. Geneva: Graduate Institute of International Studies. 